\title{
Article \\ Antimicrobial Activity and In Silico Molecular Docking Studies of Pentacyclic Spiro[oxindole-2,3'-pyrrolidines] Tethered with Succinimide Scaffolds
}

\author{
Sonia Askri ${ }^{1}$, Amal Dbeibia ${ }^{2}$, Chadlia Mchiri ${ }^{3}$, Sarra Boudriga ${ }^{4}\left(\mathbb{D}\right.$, Michael Knorr ${ }^{5, *(\mathbb{D})}$, Emmanuel Roulland ${ }^{6} \mathbb{D}$, \\ Olivier Laprévote ${ }^{6}$, Nathalie Saffon-Merceron ${ }^{7}$ and Rafik Gharbi ${ }^{1 \text {,* }}$
}

check for updates

Citation: Askri, S.; Dbeibia, A.; Mchiri, C.; Boudriga, S.; Knorr, M.; Roulland, E.; Laprévote, O.; Saffon-Merceron, N.; Gharbi, R. Antimicrobial Activity and In Silico Molecular Docking Studies of Pentacyclic Spiro[oxindole-2, $3^{\prime}$ pyrrolidines] Tethered with Succinimide Scaffolds. Appl. Sci. 2022, 12, 360. https://doi.org/ 10.3390/app12010360

Academic Editors: Lucjusz Zaprutko and Anna Pawelczyk

Received: 26 November 2021

Accepted: 25 December 2021

Published: 30 December 2021

Publisher's Note: MDPI stays neutral with regard to jurisdictional claims in published maps and institutional affiliations.

Copyright: (C) 2021 by the authors. Licensee MDPI, Basel, Switzerland. This article is an open access article distributed under the terms and conditions of the Creative Commons Attribution (CC BY) license (https:// creativecommons.org/licenses/by/ $4.0 /)$.
1 Laboratory of Environmental Chemistry \& Clean Processes Research (LR21ES04), Faculty of science of Monastir, University of Monastir, Monastir 5019, Tunisia; sonia.askri1991@gmail.com

2 Laboratory of Analyzes, Treatment and Valorization of Environmental Pollutants and Products, Faculty of Pharmacy of Monastir, University of Monastir, Monastir 5019, Tunisia; amaldbeibia@gmail.com

3 Laboratoire de Physico-Chimie des Matériaux (LPCM), Faculty of Sciences of Monastir, Avenue de L'environnement, University of Monastir, Monastir 5019, Tunisia; chadliamchiri@gmail.com

4 Laboratory of Heterocyclic Chemistry Natural Product and Reactivity (LR11ES39), Department of Chemistry, Faculty of Science of Monastir, Monastir 5019, Tunisia; sarra_boudriga@yahoo.fr

5 Institut UTINAM UMR CNRS 6213, Université Bourgogne Franche-Comté, Route de Gray, 25030 Besançon, France

6 CITCOM, UMR 8038 CNRS, Université de Paris, 4 Avenue de l'Observatoire, 75006 Paris, France emmanuel.roulland@parisdescartes.fr (E.R.); olivier.laprevote@u-paris.fr (O.L.)

7 Institut de Chimie de Toulouse UAR 2599, Université Paul Sabatier, 118 Route de Narbonne, 31062 Toulouse, France; saffon@chimie.ups-tlse.fr

* Correspondence: michael.knorr@univ-fcomte.fr (M.K.); raf_gharbi@yahoo.fr (R.G.)

\begin{abstract}
Three-component cascade reactions of (E)-3-arylidene-1-methyl-pyrrolidine-2,5-diones, $L$-valine and various isatin derivatives are described. A series of 17 spiropyrrolidine derivatives with wide structural complexity and diversity have been thus obtained in moderate to excellent yields under mild reaction conditions. The structure and stereochemistry of these $N$-heterocyclic cycloadducts has been established by spectroscopic techniques and unambiguously confirmed by a single-crystal X-ray diffraction analysis performed on one derivative. UV-visible spectra have been recorded for all new compounds. Furthermore, the synthesized $N$-heterocyclic compounds have been screened for their in vitro antibacterial and antifungal activities. Several derivatives exhibited moderate to good activities, comparable to those of the known standard drugs Amphotericin B and Tetracycline. Structural activity relationships (SARs) and molecular docking of the most promising derivatives into the binding sites of glucosamine 6-phosphate synthase (GlcN6P) and methionyl-trnasynthetase (1PFV) were also established. Furthermore, pharmacokinetic studies indicate that the heterocycles exhibit acceptable predictive ADMET (absorption, distribution, metabolism, excretion, and toxicity) properties and good drug ability.
\end{abstract}

Keywords: spirooxindolepyrrolidines; multicomponent reaction; 1,3-dipolar cycloaddition; antimicrobial activity; molecular docking analysis

\section{Introduction}

Spirocyclic oxindoles, which are widely distributed in natural alkaloids and bioactive compounds, also represent attractive synthetic targets [1-7]. As a subset of this family, spiro[oxindole-2, $3^{\prime}$-pyrrolidine] constitute a privileged structural unit which is present in numerous natural isolates and synthetic bioactive compounds [8,9]. They exhibit a wide spectrum of biological properties, such as antitumoral [10,11], anti-inflammatory [12], antimycobacterial [13], antimicrobial and anticancer activities (Figure 1) [14-17]. Furthermore, they are also known for acetylcholinesterase inhibition [18,19]. 


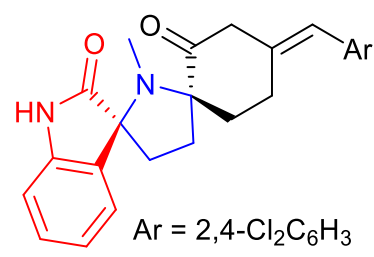

antitumoral activity ${ }^{5}$

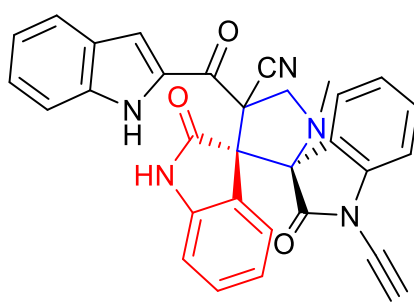

antimicrobial and anticancer activities $^{8}$

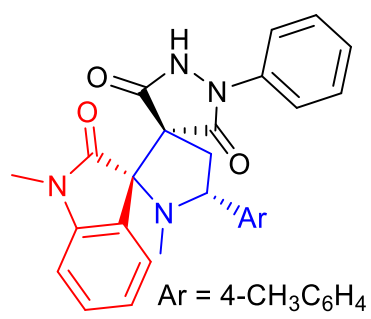

anti-inflammatory activity ${ }^{6}$

Figure 1. Examples of biologically active compounds containing spiro[oxindole-2,3'-pyrrolidine] units.

Among the current methodologies for the synthesis of spiro[oxindole-2, $3^{\prime}$-pyrrolidine] derivatives, multicomponent $(3+2)$ cycloaddition reactions (MCRs) of electron-deficient exocyclic alkenes with azomethine ylides, generated in situ by decarboxylative condensation of isatin derivatives with $\alpha$-aminoacids, have emerged as one of the most powerful tools (Scheme 1, eq. 1) [20-27]. However, a thorough literature survey of the decarboxylative process reveals that $L$-valine received only little attention as a component in the formation of azomethine ylides (Scheme 1, eq. 2). Considering this challenge, we were intrigued as to whether $\alpha$-arylidene succinimides could be employed as dipolarophiles to undergo MCRs with azomethine ylides derived from $L$-valine and isatin derivatives, thus yielding dispiro[pyrrolidine-2, $3^{\prime}$-oxindoles] bearing an isopropyl moiety at 5-position.<smiles>[R7]C([R7])=C1CCCC1</smiles>

\section{This work}<smiles>CC(C)[C@H](C)[OH+]C(=O)[C@@H](N)C(C)C</smiles>

L-valine has yet not be described as a partner in the formation of azomethine ylides

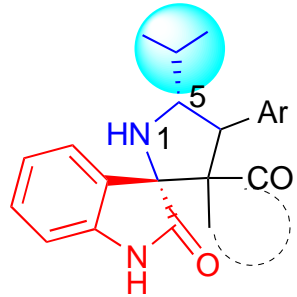

dispiro[pyrrolidine-2,3'-oxindoles] bearing an isopropyl moiety at 5-position

Scheme 1. MCR as tool for the synthesis of pentacyclic spiro[oxindole-2,3'-pyrrolidines].

Furthermore, our targeted formal $(3+2)$ cycloaddition products 5 bear succinimide scaffolds. These latter five-membered $\left(\mathrm{CH}_{2}\right)_{2}(\mathrm{CO})_{2} \mathrm{NH}$ or $\left(\mathrm{CH}_{2}\right)_{2}(\mathrm{CO})_{2} \mathrm{NR}$ cycles constitute important skeletons in numerous alkaloids, including Hirsutellone A and B 7, drug molecules and various other bioactive synthetic compounds. Some succinimide derivatives, for instance, are used as antimycobacterial agents for the treatment of mycobacteria infections [28,29] and for the suppression of cancer cell proliferation [30]. Several succinimides are furthermore used as anticonvulsant drugs, including ethosuximide (Zarontin), phensuximide, and methsuximide (Petinutin) [31,32]. Recently, we showed that some spirooxindolepyrrolidine and spirooxindolepyrrolizidine derivatives incorporating the pyrrolidine-2,5-dione motif are promising for acetylcholinesterase (AChE) inhibition [33] and possess both antimicrobial and anticoagulant activities [34].

Herein, and in continuation of our research in the domain of one-pot MCRs of azomethine ylides [33-41], we report on the synthesis of various spiro[oxindole-2,3'-pyrrolidines] 
tethered with succinimide derivatives. The latter were assembled by a one-pot threecomponent [3+2]-cycloaddition reaction of isatin itself or halogenated isatin derivatives 1, L-valine 2 and (E)-3-arylidene-1-methyl-succinimides 4 . Note that isatin and its analogues also constitute an important class of organic compounds featuring biological and pharmacological proprieties and serve as building blocks for further transformation. To valorize the synthetic results, some selected heterocyclic compounds were screened in vitro to evaluate their antimicrobial activity and the structure-activity relationship (SAR) was supported by a molecular docking analysis.

\section{Results and Discussion}

\subsection{Synthetic Chemistry}

At the onset of our work, 5-chloroisatin 1a, $L$-valine 2 and dipolarophile $4 \mathbf{d}$ were probed as model substrates to optimize the reaction conditions leading to pentacyclic compound $\mathbf{5 d}$ (Scheme 2). The effects of solvents and temperature on the reaction time and yield were examined and the results are summarized in Table 1.

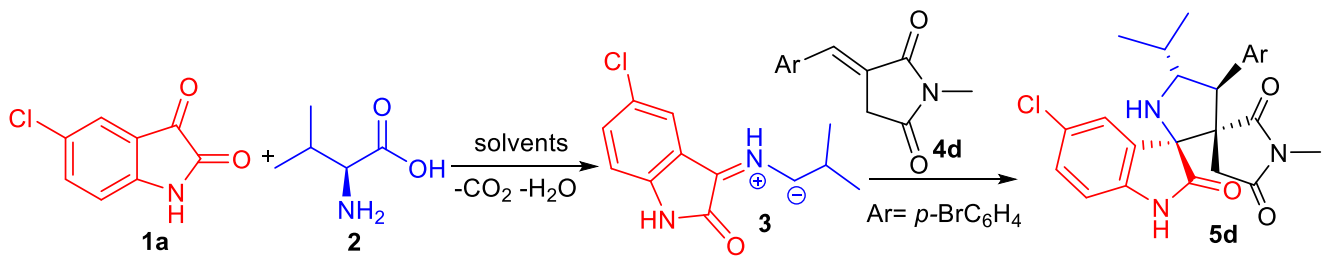

Scheme 2. 1,3-Dipolar cycloaddition affording spirooxindole 5d.

Table 1. Optimization of the reaction parameters for the synthesis of $\mathbf{5} \mathbf{d}^{\mathbf{a}}$.

\begin{tabular}{ccccc}
\hline Entry & Solvent & T $\left({ }^{\circ} \mathbf{C}\right)$ & Time (h) & Yield (\%) $\mathbf{b}^{\mathbf{b}}$ \\
\hline 1 & $\mathrm{PhCH}_{3}$ & 110 & 24 & 69 \\
2 & $\mathrm{CH}_{3} \mathrm{CN}$ & 80 & 13 & 83 \\
3 & $\mathrm{EtOH}$ & 78 & 12 & 65 \\
4 & $\mathbf{M e O H}$ & 64 & 3 & $\mathbf{9 6}$ \\
5 & $\mathrm{THF}$ & 70 & 36 & 20
\end{tabular}

a The reaction of $1 \mathrm{a}(0.5 \mathrm{mmol}), 2(0.6 \mathrm{mmol})$ and $4 \mathrm{~d}(0.5 \mathrm{mmol})$ carried out in various solvents $(5.0 \mathrm{~mL}) .{ }^{\mathrm{b}}$ Yield of the isolated product after purification.

Compound 5d was isolated only with a low yield when the reaction was carried out in tetrahydrofuran (Table 1, entry 5). However, in refluxing methanol, the 1,3-dipolar cycloaddition reaction proceeds smoothly afforded the targeted spiro[oxindole-2,3'-pyrrolidine] $\mathbf{5 d}$ with an excellent yield of $96 \%$ (Table 1, entry 4 ) as a racemic mixture.

Having once established the optimal conditions (Table 1, entry 4), we next examined the scope of the reaction in regard to diverse $\alpha$-arylidene-succinimides 4 , as well as with isatin1c and various halogenated isatin derivatives 1a,b (Schema 3, Table 2). 
Table 2. Synthesis of the spirooxindole pyrrolidines $5^{\mathrm{a}}$.

\begin{tabular}{|c|c|c|c|c|}
\hline Entry & Compounds & $\mathbf{R}$ & Ar & Yield $(\%)^{b}$ \\
\hline 1 & $5 a$ & $\mathrm{Cl}$ & $\mathrm{C}_{6} \mathrm{H}_{5}$ & 72 \\
\hline 2 & $5 b$ & $\mathrm{Cl}$ & $p-\mathrm{MeC}_{6} \mathrm{H}_{4}$ & 66 \\
\hline 3 & $5 c$ & $\mathrm{Cl}$ & $p-\mathrm{MeOC}_{6} \mathrm{H}_{4}$ & 86 \\
\hline 4 & $5 d$ & $\mathrm{Cl}$ & $p-\mathrm{BrC}_{6} \mathrm{H}_{4}$ & 96 \\
\hline 5 & $5 e$ & $\mathrm{Cl}$ & $\begin{array}{c}m, m^{\prime}, p- \\
(\mathrm{MeO}){ }_{3} \mathrm{C}_{6} \mathrm{H}_{2}\end{array}$ & 75 \\
\hline 6 & $5 f$ & $\mathrm{Cl}$ & $m-B r, p-\mathrm{OHC}_{6} \mathrm{H}_{3}$ & 73 \\
\hline 7 & $5 g$ & $\mathrm{Cl}$ & $\begin{array}{c}m, m^{\prime}-(\mathrm{MeO})_{2}, p- \\
\mathrm{OHC}_{6} \mathrm{H}_{2}\end{array}$ & 66 \\
\hline 8 & $5 \mathrm{~h}$ & $\mathrm{Cl}$ & $\begin{array}{c}m, m^{\prime}-\mathrm{Br}_{2}, p- \\
\mathrm{OHC}_{6} \mathrm{H}_{2}\end{array}$ & 70 \\
\hline 9 & $5 i$ & $\mathrm{~F}$ & $\mathrm{C}_{6} \mathrm{H}_{5}$ & 52 \\
\hline 10 & $5 \mathbf{j}$ & $\mathrm{F}$ & $p-\mathrm{Me} \mathrm{C}_{6} \mathrm{H}_{4}$ & 53 \\
\hline 11 & $5 \mathrm{k}$ & $\mathrm{F}$ & $p-\mathrm{MeOC}_{6} \mathrm{H}_{4}$ & 55 \\
\hline 12 & 51 & $\mathrm{~F}$ & $p-\mathrm{BrC}_{6} \mathrm{H}_{4}$ & 52 \\
\hline 13 & $5 \mathrm{~m}$ & F & $\begin{array}{c}m, m^{\prime}, p- \\
(\mathrm{MeO}){ }_{3} \mathrm{C}_{6} \mathrm{H}_{2}\end{array}$ & 58 \\
\hline 14 & $5 n$ & $\mathrm{~F}$ & $m-\mathrm{Br}, p-\mathrm{OHC}{ }_{6} \mathrm{H}_{3}$ & 80 \\
\hline 15 & 50 & $\mathrm{~F}$ & $\begin{array}{c}m, m^{\prime}-(\mathrm{MeO})_{2}, p- \\
\mathrm{OHC}_{6} \mathrm{H}_{2}\end{array}$ & 56 \\
\hline 16 & $5 p$ & $\mathrm{~F}$ & $\begin{array}{l}m, m^{\prime}-\mathrm{Br}_{2}, p- \\
\mathrm{OHC}_{6} \mathrm{H}_{2}\end{array}$ & 51 \\
\hline 17 & $5 q$ & $\mathrm{H}$ & $p-\mathrm{MeOC}_{6} \mathrm{H}_{4}$ & 83 \\
\hline
\end{tabular}

a Reactions were carried out with $1(1 \mathrm{mmol}), 2(1.2 \mathrm{mmol})$ and $4(1 \mathrm{mmol})$ in methanol $(10 \mathrm{~mL})$ at $64{ }^{\circ} \mathrm{C}$ for $3 \mathrm{~h}$

$\mathrm{b}$ Isolated yield after purification by column chromatography.

The electronic properties and position of the substituent on the aromatic cycle of dipolarophiles 4 had no substantial influence on the efficiency of this reaction. As summarized in Table 2, arylidene-succinimides 4 bearing an electron-neutral $(\mathrm{H})$, electron-donating (e.g., 4-Me, 3-OMe, 4-OMe or 4-OH) groups or electron-withdrawing substituent (4-Br, $3-\mathrm{Br}$ ) reacted smoothly to afford the desired spiro[oxindole-2,3'-pyrrolidine] derivatives 5a-5q in good to excellent yields. In addition, 5-fluorooisatin 1c was a suitable substrate under standard conditions, although compounds $5 \mathbf{i}-5$ p were obtained with somewhat lower yields (Table 2, entries 9-16). No spectroscopic evidence for a competing formation of isomeric compounds 6 bearing the succinimide ring at 4-position (Scheme 3).

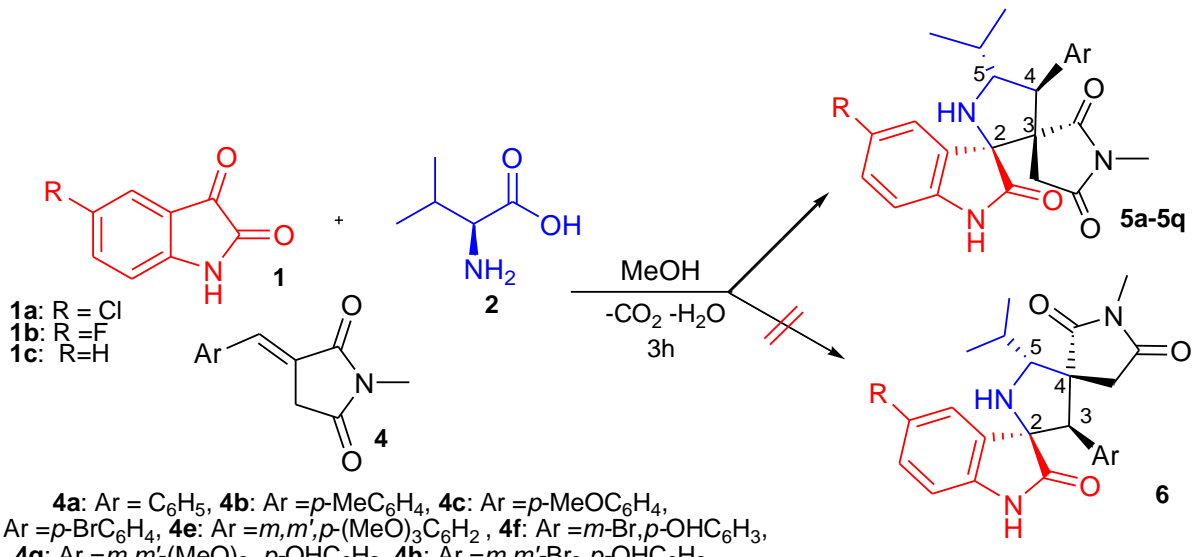

4d: $\mathrm{Ar}=p-\mathrm{BrC}_{6} \mathrm{H}_{4}, \mathbf{4 e}: \mathrm{Ar}=m, m^{\prime}, p-(\mathrm{MeO})_{3} \mathrm{C}_{6} \mathrm{H}_{2}, \mathbf{4 f}: \mathrm{Ar}=m-\mathrm{Br}, p-\mathrm{OHC}_{6} \mathrm{H}_{3}$

4g: $\mathrm{Ar}=m, m^{\prime}-(\mathrm{MeO})_{2}, p-\mathrm{OHC}_{6} \mathrm{H}_{2}, \mathbf{4 h}: \mathrm{Ar}=m, m^{\prime}-\mathrm{Br}_{2}, p-\mathrm{OHC}_{6} \mathrm{H}_{2}$

Scheme 3. 1,3-Dipolar cycloaddition route for the synthesis of spirooxindolepyrrolidines 5. 


\subsection{Spectroscopic and Crystallographic Characterization of the Cycloadducts $\mathbf{5}$}

The structure and the relative configuration of the spiro-adducts 5 was deduced by NMR spectroscopy. As a representative example, $\mathbf{5 b}$ has been chosen and selected ${ }^{1} \mathrm{H}$ and ${ }^{13} \mathrm{C}$ chemical shifts along with some characteristic coupling constants are shown in Figure 2.

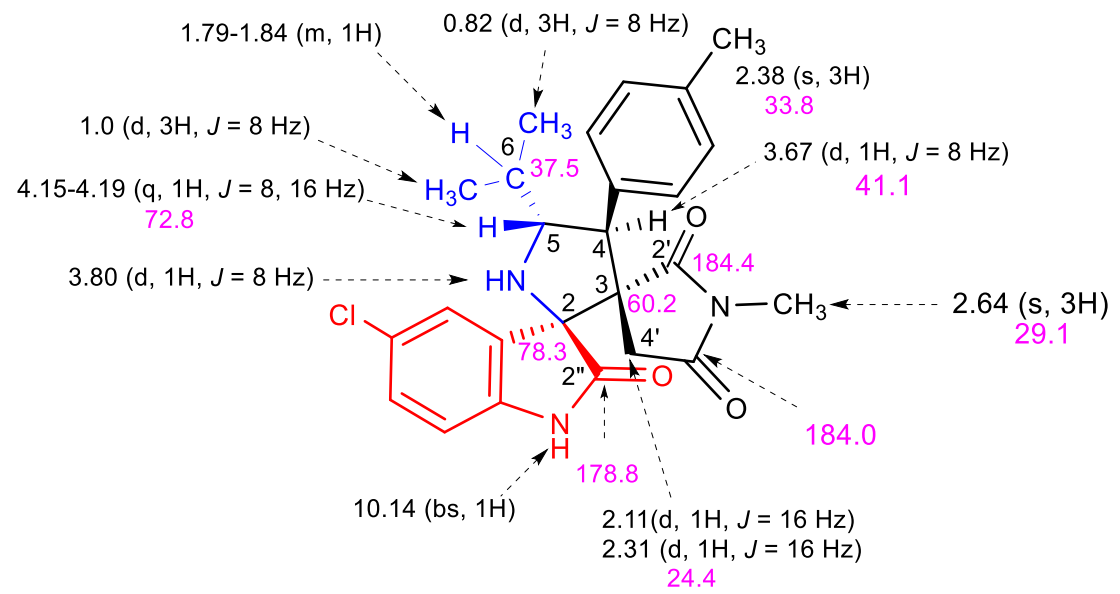

Figure 2. ${ }^{1} \mathrm{H}$ (black) chemical shifts with coupling constants and ${ }^{13} \mathrm{C}$ NMR (pink) data (ppm) of $\mathbf{5 b}$.

The ${ }^{1} \mathrm{H}$ NMR spectrum of $5 \mathbf{b}$ shows a singlet at $\delta 2.64 \mathrm{ppm}$ due to the $N$-methyl protons. Two mutually coupled doublets are observed at $\delta 2.10$ and $2.31 \mathrm{ppm}(J=16 \mathrm{~Hz})$ corresponding to the diastereotopic4' $-\mathrm{CH}_{2}$ group of the pyrrolide-2,5-dione cycle. A doublet at $\delta 3.67 \mathrm{ppm}(J=8 \mathrm{~Hz})$ and quadruplet-like multiplet at $\delta 4.15-4.19 \mathrm{ppm}(J=6.8 \mathrm{~Hz}$, $J=14 \mathrm{~Hz}$ ) are assigned to the pyrrolidine $\mathrm{H}-4$ and $\mathrm{H}-5$ protons, respectively. The multiplicity of these signals clearly demonstrates the regiochemistry of the 1,3-dipolar cycloaddition reaction. If the alternative other regioisomer $\mathbf{6 b}$ (Scheme 3 ) would have been formed, the pyrrolidinyl H-3 and $\mathrm{H}-5$ protons should give rise to a singlet and doublet of doublet pattern in the ${ }^{1} \mathrm{H}$ NMR spectrum.

The aromatic protons give rise to a multiplet in the region $\delta 6.77-7.31 \mathrm{ppm}$ and a broad singlet at $\delta 10.62 \mathrm{ppm}$ is attributed to the $\mathrm{NH}$ proton of the oxindole motif. In addition, a doublet at $\delta 3.80 \mathrm{ppm}$ can be assigned to the $\mathrm{NH}$ proton of the pyrrolidine ring.

The proton decoupled ${ }^{13} \mathrm{C}$ NMR spectrum of $\mathbf{5 b}$ exhibits signals at $\delta 41.1$ and $72.8 \mathrm{ppm}$ corresponding to the C-4 and C-5 carbons. The two spiranic carbons C-3 and C-2 resonate at $\delta 60.2$ and $78.8 \mathrm{ppm}$, respectively. In addition, the oxindole carbonyl carbon is recognized at 178.8 and two further signals resonating at $\delta 184.0$ and $184.4 \mathrm{ppm}$ are attributed to the succinimide carbonyl carbons.

The regio- and stereochemical outcome of the reaction was finally ascertained by an $\mathrm{X}$-ray study, allowing elucidation of the molecular structure of $\mathbf{5 b}$, and confirming that the isopropyl and aryl group stemming from the dipolarophile are in a transoid configuration.

The crystallographic data and the structural refinement details are reported in Table S1 (Supplementary Materials). The asymmetric unit contains two independent molecules. A thermal ellipsoid plot with the atom numbering is shown in Figure 3, and selected bond distances and angles are listed in Table S2.

The solid-state structure of compound $\mathbf{5 b}$ is stabilized through significant intermolecular interactions such as $\mathrm{N}-\mathrm{H} \cdots \mathrm{N}, \mathrm{N}-\mathrm{H} \cdots \mathrm{O}, \mathrm{C}-\mathrm{H} . \cdots \mathrm{Cl}$ and $\mathrm{C}-\mathrm{H} \cdots \mathrm{O}$ hydrogen bonding (Table S2). Within the supramolecular crystal structure of $\mathbf{5 b}$ (Figure 4), the two independent molecules are linked together via weak non-conventional intermolecular H-bonding interactions. Thus, the N2 atom of the pyrrolidine ring of the first molecule is involved in a $\mathrm{N} 4-\mathrm{H} 4 \cdots \mathrm{N} 2 \mathrm{H}-$ bond with the $\mathrm{H} 4$ atom of the pyrrolidine ring of the second molecule with a separation of 2.871(2) $\AA$. The H5A atom of the pyrrolidine ring in the second molecule is also involved in another N5-H5A ... O6 H-bond with the O6 oxygen atom of pyrrolidine2,5-dionering of another nearby molecule with a length of 2.957(2) $\AA$ (Figure 4a). In addition, this crystal packing is reinforced by several weak $\mathrm{C}-\mathrm{H} \cdots \mathrm{O}$ interactions between the $\mathrm{H} 16 \mathrm{~A}$ 
atom of the pyrrolidine-2,5-dione group of one molecule and the $\mathrm{O} 5$ oxygen atom of the same group of another molecule, with a C16-H16A.... 55 distance of $2.943 \AA$.

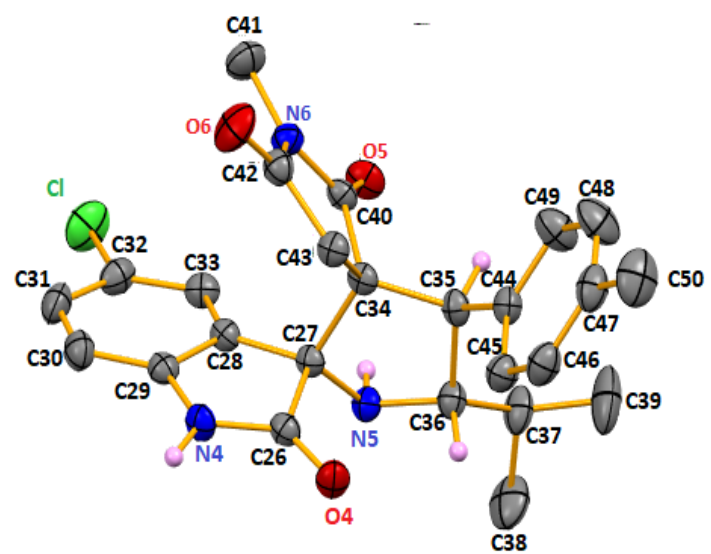

Figure 3. The molecular structure of one of the two independent molecules of $\mathbf{5 b}$, showing the atom-numbering scheme. The displacement ellipsoids drawn at the $50 \%$ probability level. Only relevant $\mathrm{H}$ atoms are shown for clarity.
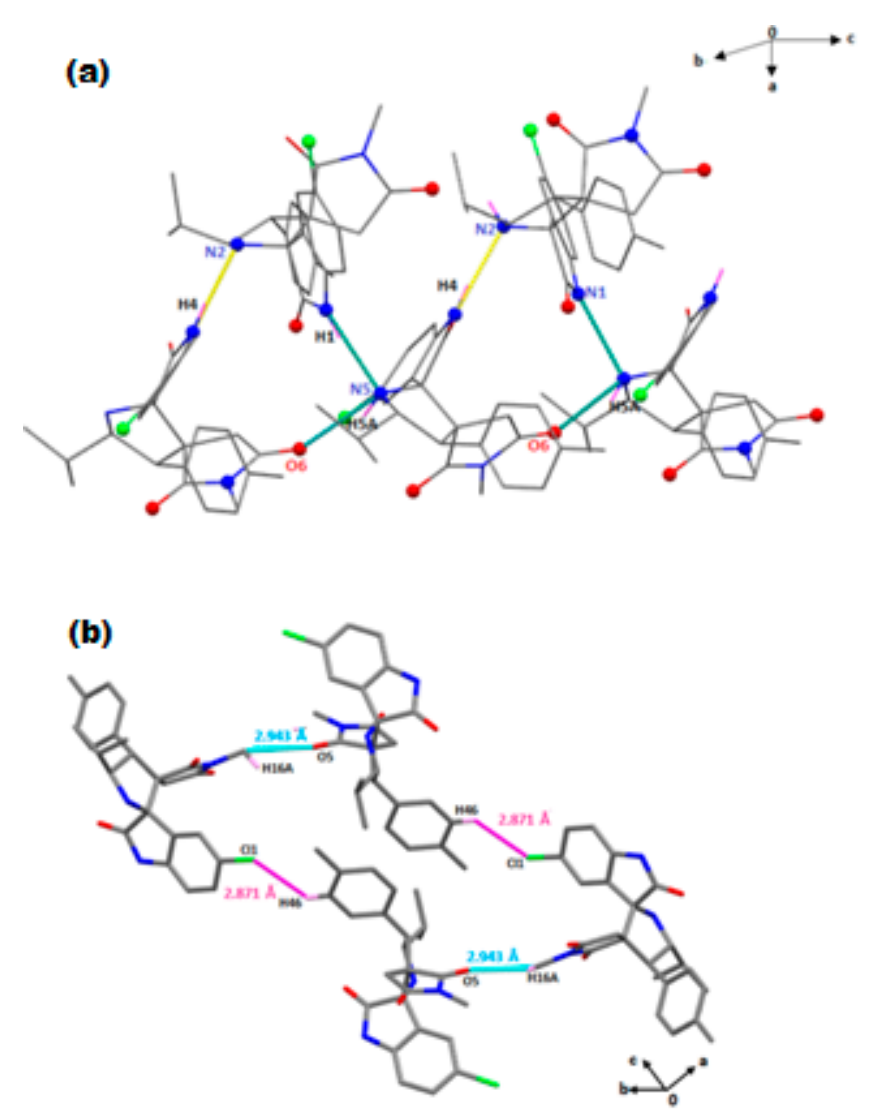

Figure 4. (a) Representation of the $\mathrm{N}-\mathrm{H} \cdots \mathrm{N}$ and $\mathrm{N}-\mathrm{H} \cdots \mathrm{O}$ bonding between two adjacent molecules of $\mathbf{5 b}$. Intermolecular interactions contacts are shown as dashed lines. (b) Presentation of the intermolecular $\mathrm{C}-\mathrm{H} \cdots \mathrm{Cl}$ and $\mathrm{C}-\mathrm{H} \cdots \mathrm{O}$ contacts occurring in $5 \mathbf{b}$.

A similar contact also occurs between the $\mathrm{H} 46$ atom of the phenyl ring of one molecule and the $p$-chloroaryl substituent of a neighbored molecule (C46-H46…Cl1, 2.871 $\AA$ (Figure $4 \mathrm{~b}$ ). Further details of the intermolecular interactions present in $\mathbf{5 b}$ are listed in Table S2. 


\subsection{Mecanistic Discussion}

To explain the stereochemical outcome in line with antecedent studies and our previous experimental findings [33-41], we propose in Scheme 4 a plausible mechanism for the regioselective and stereoselective formation of the spiro[oxindole-2, $3^{\prime}$-pyridine].

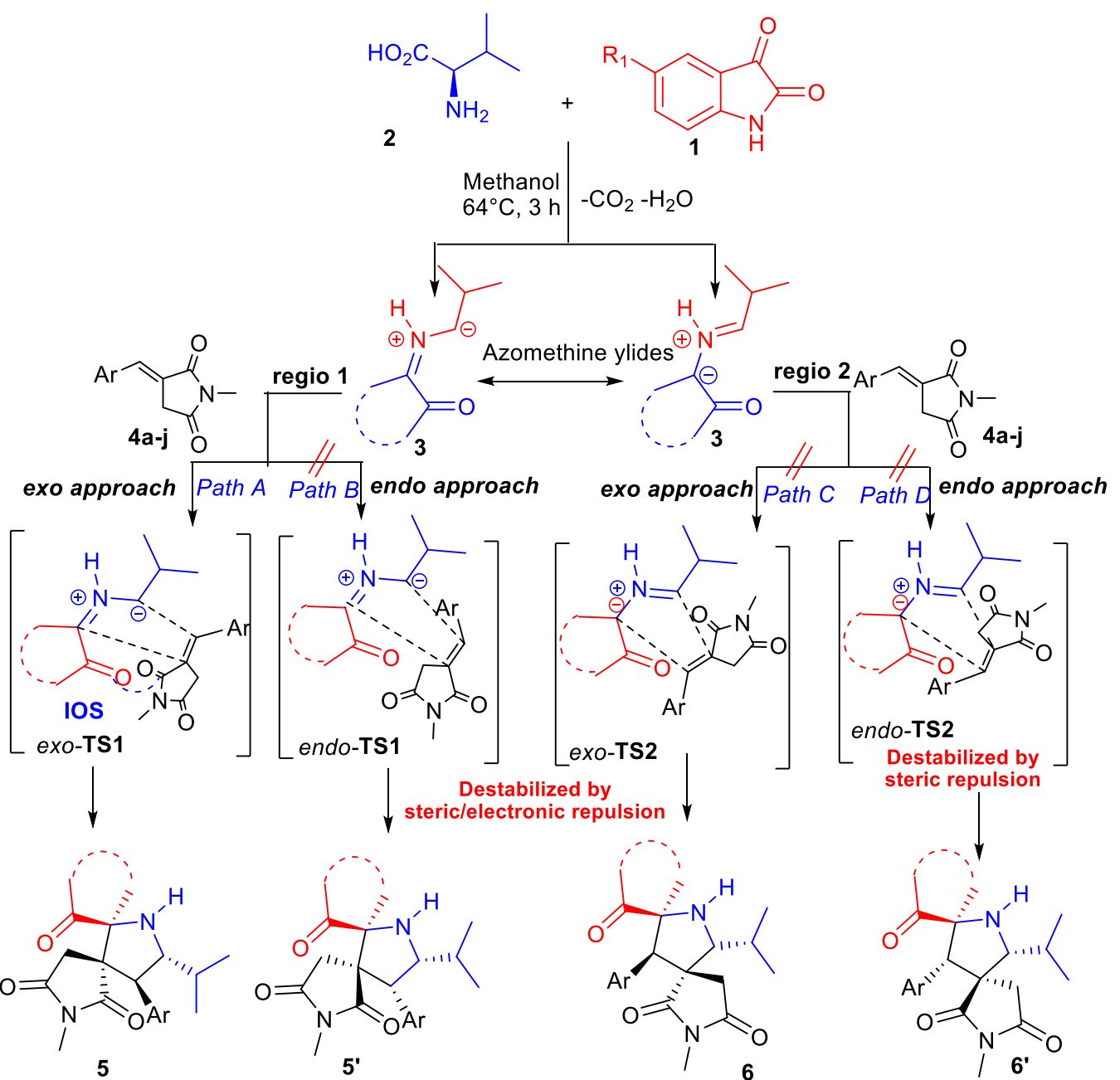

Scheme 4. Suggested mechanism for the 1,3-dipolar cycloaddition of azomethine ylides across (E)-3-arylidene-1-metyl-pyrrolidine-2,5-diones 4.

First, the in situ decarboxylative condensation of isatin derivatives 1 with $L$-valine 2 generates the $(Z, E)$-dipole 3 . Then the azomethine ylide subsequently undergoes a 1,3 dipolar cycloaddition reaction across the dipolarophile 4. A priori, two regioisomeric and two stereoisomeric pathways can be taken in consideration. The exo- and endo-approaches refer to the approach of the dipolarophile with its electron-withdrawing group (carbonyl group) oriented toward the EWG group of the dipole (carboxamide group of oxindole) or away from it, respectively. The presence of a secondary orbital interaction (SOI) [42], via path $A$, favors more the formation of the exo-regioisomer 5 , which occurs between the oxygen atom of the carbonyl of the diketone and the carbon atom of the carbonyl succinimide acting as dipolarophile according to Scheme 4 . The formation of the alternative regioisomers or diastereoisomers $5^{\prime}$ or $6 / 6^{\prime}$ via pathways $B, C$ and $D$ is probably less favorable because of steric or electronic repulsion occurring in their corresponding transition states. We are aware that, apart from SOI interactions, other parameters, such as reaction temperature $[35,40]$ or the choice of the solvent [43], may also impact the stereochemical outcome. To confirm our mechanistic proposal, DFT computing is intended in prospective work. 


\subsection{Electronic Properties: UV-Visible Absorption Spectroscopy}

The absorption spectral data recorded in DMSO as solvent for the spiro[pyrrolidin2,3-oxindoles]5 are summarized in Table 3. As representative example, the superposition of the electronic absorption spectra of $5 \mathrm{c}, 5 \mathrm{~g}$ and $\mathbf{5 h}$ using a dilute concentration around $10^{-5} \mathrm{M}$ are depicted in Figure 5.

Table 3. UV-vis maxima and optical gap (eV) for series 5.

\begin{tabular}{|c|c|c|c|}
\hline Compounds & $\lambda_{\max }(\mathrm{nm})$ & $\begin{array}{c}\lambda_{\mathrm{abs}}(\mathrm{nm})(\log (\varepsilon) \\
\left.\mathrm{M}^{-1} \mathrm{~cm}^{-1}\right)\end{array}$ & $\mathrm{Eg}(\mathrm{eV})$ \\
\hline $5 a$ & 300 & & \\
\hline $5 b$ & 300 & & \\
\hline $5 c$ & 307 & & \\
\hline $5 d$ & 320 & & \\
\hline $5 e$ & 310 & & \\
\hline $5 f$ & 320 & 420 & 2.60 \\
\hline $5 g$ & 340 & 454 & 2.44 \\
\hline $5 \mathrm{~h}$ & 340 & 410 & 2.53 \\
\hline $5 i$ & 290 & & \\
\hline $5 \mathbf{j}$ & 300 & & \\
\hline $5 \mathrm{k}$ & 300 & & \\
\hline 51 & 295 & & \\
\hline $5 \mathrm{~m}$ & 297 & & \\
\hline $5 n$ & 320 & 418 & 2.67 \\
\hline 50 & 320 & 420 & 2.60 \\
\hline $5 p$ & 340 & 409 & 2.69 \\
\hline $5 q$ & 298 & & \\
\hline
\end{tabular}

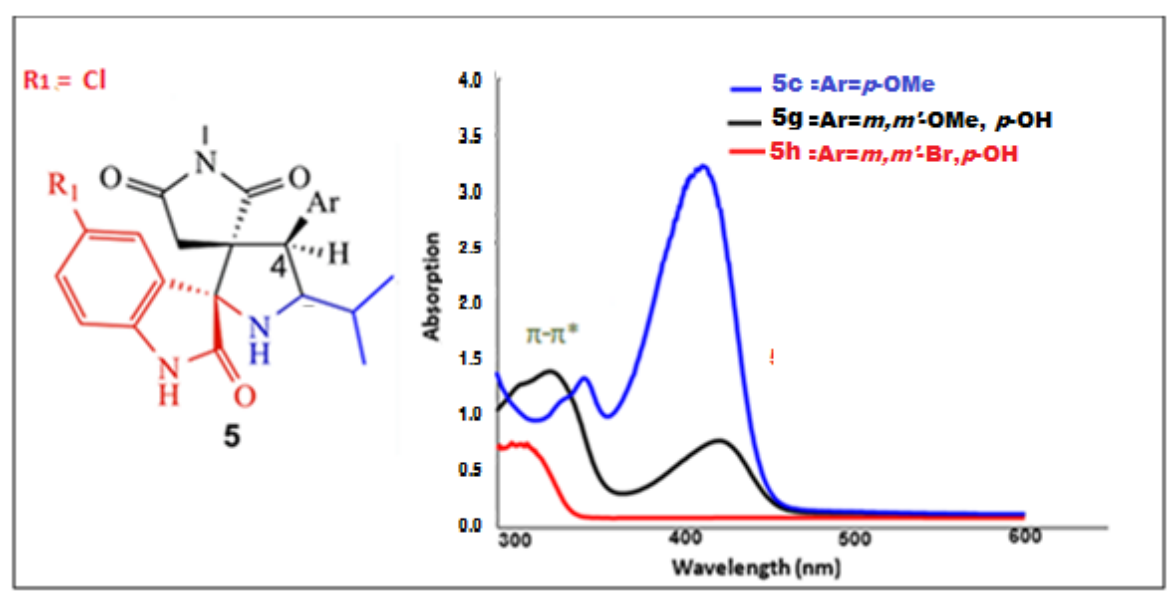

Figure 5. UV-visible absorption spectra in DMSO $\left(c=10^{-5} \mathrm{M}\right)$ at $298 \mathrm{~K}$ of compounds $\mathbf{5} \mathbf{c}, \mathbf{5} \mathbf{g}$ and5h.

The broad absorption band with $\lambda_{\text {abs }}$ in the range $290-340 \mathrm{~nm}$ can be assigned due to $\pi-\pi^{*}$ transitions. Additionally, in the case of $p$-hydroxyspiro[pyrrolidin-2,3-oxindoles $\mathbf{5 f - h}$ and $5 \mathrm{n}-\mathrm{p}$, the appearance of a second high intensity band within the 409-454 $\mathrm{nm}$ region is noticeable. The intense absorptions can be attributed to an intramolecular charge transfer (ICT) transition involving to hydroxy group [44] (Figure 5) and (Table 3).

This CT-band is red-shifted for compounds $\mathbf{5 h}$ and $\mathbf{5 o}$, where the methoxy group is attached at 3,5-positions. The bathochromic effect on the charge transfer band is mainly due to the electron-withdrawing propensity of $\mathrm{OCH}_{3}$ in an inductive sense [45]. In contrast, a hypsochromic shift is noticed for $p$-hydroxyspiro[pyrrolidin-2,3-oxindoles $5 \mathbf{h}$ and $5 \mathrm{p}$ bearing bromo substituents.

The optical gap ( $E_{\text {gap-op }}$ ) refers to the energetic separation between the HOMO and the LUMO frontier orbitales of the spiropyrrolidine oxindoles. To determine the optical 
bandgap, we used the UV-visible spectrum, employing the Tauc plot method [46]. The Egap values in DMSO solution are $2.44 \mathrm{eV}$ and $2.69 \mathrm{eV}$ for $\mathbf{5 i}$ and $\mathbf{5 p}$, respectively (Table 3 ).

\subsection{Antimicrobial Screening}

The antibacterial activity of the pentacyclic compounds was screened against four bacteria strains, namely Staphylococcus aureus ATCC 25,923 (S.A.), Micrococcus luteus NCIMB 8166 (M.L), Escherichia coli ATCC 25,922 (E.C.) and Pseudomonas aeruginosa ATCC 27,853 (P.A.). Tetracycline (Tet. https://en.wikipedia.org/wiki/Tetracycline, accessed on 13 December 2021) was used as standard antibacterial agent. Furthermore, the antifungal activity of the products was tested against two pathogenic reference yeasts, namely Candida albicans ATCC 90,028 (C.A.) and Candida krusei ATCC 6258 (C.K.). Amphotericin B (Amp B https:/ / en.wikipedia.org/wiki/Amphotericin_B, accessed on 13 December 2021.) has been used as a standard antifungal agent.

The determinations of the minimal inhibition concentrations (MIC) and the minimal bactericidal/fungicidal concentrations (MBC/MFC) were conducted following the technique of dilution in liquid medium, as described by Snoussi et al. [47].

When tested on different microorganism strains, the compounds were found to display significant activity. The potencies were qualitatively assessed by the presence or the absence of an inhibition zone diameter (Figures 6 and 7). The MIC, MBC and MFC values are presented in Tables 4-6, respectively.

Table 4. Antibacterial and antifungal activity (MIC in $\mu \mathrm{g} / \mathrm{mL}$ ).

\begin{tabular}{|c|c|c|c|c|c|c|}
\hline \multirow[b]{3}{*}{ Comp. } & \multicolumn{4}{|c|}{ Bacterial Strains } & & \\
\hline & \multicolumn{2}{|c|}{ Gram-Positive Bacteria } & \multicolumn{2}{|c|}{ Gram-Negative Bacteria } & \multicolumn{2}{|c|}{ Yeast Strains } \\
\hline & $\begin{array}{c}\text { S. aureus } \\
\text { ATCC } 25923\end{array}$ & $\begin{array}{c}\text { M. luteus } \\
\text { NCIMB } 8166\end{array}$ & $\begin{array}{c}\text { E. coli } \\
\text { ATCC } 25922\end{array}$ & $\begin{array}{l}\text { P. aeroginosa } \\
\text { ATCC } 27853\end{array}$ & $\begin{array}{c}\text { C. albicans } \\
\text { ATCC } 90028\end{array}$ & $\begin{array}{c}\text { C. krusei } \\
\text { ATCC } 6258\end{array}$ \\
\hline $5 a$ & 3.9 & NA & NA & 250 & 7.8 & 31.5 \\
\hline $5 b$ & 500 & 250 & 250 & NA & 250 & 125 \\
\hline $5 c$ & NA & 250 & NA & NA & 62.5 & NA \\
\hline $5 d$ & 31.5 & 250 & NA & NA & 125 & 125 \\
\hline $5 e$ & 31.5 & 250 & 500 & NA & NA & NA \\
\hline $5 f$ & NA & 125 & NA & NA & 7.8 & 250 \\
\hline $5 g$ & 31.5 & 125 & NA & 250 & 125 & 125 \\
\hline $5 h$ & 250 & 31.5 & NA & NA & 250 & 250 \\
\hline $5 i$ & 3.9 & 125 & 250 & 250 & 7.8 & 62.5 \\
\hline $5 \mathbf{j}$ & 500 & 250 & 250 & NA & 250 & 1000 \\
\hline $5 k$ & 1000 & 500 & NA & NA & 125 & 250 \\
\hline 51 & 62.5 & 500 & NA & NA & NA & NA \\
\hline $5 \mathrm{~m}$ & 125 & 1000 & NA & NA & 250 & 250 \\
\hline $5 n$ & NA & 125 & NA & NA & NA & NA \\
\hline 50 & 250 & 31.5 & NA & NA & 500 & 250 \\
\hline $5 p$ & 250 & 62.5 & NA & NA & 31.5 & 125 \\
\hline $5 q$ & 500 & 500 & NA & NA & 125 & 250 \\
\hline Tet. & $24 \pm 0$ & $12 \pm 0.1$ & $9 \pm 0$ & $11 \pm 1.1$ & NT & NT \\
\hline Amp. B & NT & NT & NT & NT & $15 \pm 0.58$ & $14 \pm 0.1$ \\
\hline
\end{tabular}

Tet.: Tetracycline; Amp. B: Amphotericin B; MIC: Minimum Inhibition Concentration; NA: no activity. 
Table 5. Antibacterial and antifungal activity of series 5 (Inhibition zone in $\mathrm{mm}$ ).

\begin{tabular}{|c|c|c|c|c|c|c|}
\hline \multirow[b]{2}{*}{ Comp. } & \multicolumn{4}{|c|}{ Bacterial Strains } & \multicolumn{2}{|c|}{ Yeast Strains } \\
\hline & $\begin{array}{c}\text { S. aureus } \\
\text { ATCC } 25923\end{array}$ & $\begin{array}{c}\text { M. luteus } \\
\text { NCIMB } 8166\end{array}$ & $\begin{array}{c}\text { E. coli } \\
\text { ATCC } 25922\end{array}$ & $\begin{array}{c}\text { P. aeroginosa } \\
\text { ATCC } 27853\end{array}$ & $\begin{array}{c}\text { C. albicans } \\
\text { ATCC } 90028\end{array}$ & $\begin{array}{c}\text { C. krusei } \\
\text { ATCC } 6258\end{array}$ \\
\hline $5 a$ & $31 \pm 0.03$ & NA & NA & $9 \pm 0$ & $12 \pm 0$ & $11 \pm 0$ \\
\hline $5 b$ & $17 \pm 0$ & $10 \pm 0$ & $8 \pm 0$ & NA & $14 \pm 0$ & $11 \pm 0$ \\
\hline $5 c$ & NA & $10 \pm 0$ & NA & NA & $7 \pm 0.2$ & NA \\
\hline $5 d$ & $12 \pm 0$ & $17 \pm 0.01$ & NA & NA & $11 \pm 0$ & $10 \pm 0$ \\
\hline $5 e$ & $11 \pm 0$ & $9 \pm 0$ & $15 \pm 0$ & NA & NA & NA \\
\hline $5 f$ & NA & $11 \pm 0$ & NA & NA & $12 \pm 0$ & $8 \pm 0$ \\
\hline $5 \mathrm{~g}$ & $18 \pm 0$ & $12 \pm 0$ & NA & $8 \pm 0$ & $12 \pm 0$ & $14 \pm 0$ \\
\hline $5 h$ & $20 \pm 0$ & $10 \pm 0$ & NA & NA & $7 \pm 0$ & $8 \pm 0$ \\
\hline $5 i$ & $19 \pm 0$ & $11 \pm 0$ & $8 \pm 0$ & $8 \pm 0.02$ & $12 \pm 0.1$ & $12 \pm 0$ \\
\hline $5 \mathbf{j}$ & $12 \pm 0$ & $12 \pm 0$ & $9 \pm 0$ & NA & $12 \pm 0$ & $11 \pm 0$ \\
\hline $5 \mathbf{k}$ & $11 \pm 0$ & $10 \pm 0$ & NA & NA & $9 \pm 0$ & $9 \pm 0$ \\
\hline 51 & $12 \pm 0$ & $13 \pm 0$ & NA & NA & NA & NA \\
\hline $5 \mathrm{~m}$ & $9 \pm 0.1$ & $9 \pm 0$ & NA & NA & $11 \pm 0$ & $11 \pm 0$ \\
\hline $5 n$ & NA & $13 \pm 0$ & NA & NA & $6 \pm 0$ & NA \\
\hline 50 & $19 \pm 0$ & $14 \pm 0$ & NA & NA & $12 \pm 0.1$ & $12 \pm 0$ \\
\hline $5 p$ & $20 \pm 0$ & $15 \pm 0$ & NA & NA & $9 \pm 0$ & $9 \pm 0$ \\
\hline $5 q$ & $9 \pm 0$ & $9 \pm 0$ & NA & NA & $10 \pm 0$ & $10 \pm 0$ \\
\hline Tet. & $24 \pm 0$ & $12 \pm 0.1$ & $9 \pm 0$ & $11 \pm 1.1$ & NT & NT \\
\hline Amp. B & NT & NT & NT & NT & $15 \pm 0.58$ & $14 \pm 0.1$ \\
\hline
\end{tabular}

Tet.: Tetracycline; Amp. B: Amphotericin B; NA: no activity; NT: not probed.

Table 6. Antibacterial and antifungal activity (MBC and MFC in $\mu \mathrm{g} / \mathrm{mL}$ ).

\begin{tabular}{|c|c|c|c|c|c|c|}
\hline \multirow[b]{3}{*}{ Comp. } & \multicolumn{4}{|c|}{ Bacterial Strains } & & \\
\hline & \multicolumn{2}{|c|}{ Gram-Positive Bacteria } & \multicolumn{2}{|c|}{ Gram-Negative Bacteria } & \multicolumn{2}{|c|}{ Yeast Strains } \\
\hline & $\begin{array}{c}\text { S. aureus } \\
\text { ATCC } 25923\end{array}$ & $\begin{array}{c}\text { M. luteus } \\
\text { NCIMB } 8166\end{array}$ & $\begin{array}{c}\text { E. coli } \\
\text { ATCC } 25922\end{array}$ & $\begin{array}{l}\text { P. aeroginosa } \\
\text { ATCC } 27853\end{array}$ & $\begin{array}{c}\text { C. albicans } \\
\text { ATCC } 90028\end{array}$ & $\begin{array}{c}\text { C. krusei } \\
\text { ATCC } 6258\end{array}$ \\
\hline $5 a$ & 31.5 & 1000 & 500 & 250 & 7.8 & 31.5 \\
\hline $5 b$ & 1000 & $>1000$ & $>1000$ & 1000 & 125 & 500 \\
\hline $5 c$ & NA & $>1000$ & NA & NA & 62.5 & NA \\
\hline $5 d$ & 62.5 & $>1000$ & NA & NA & 125 & 125 \\
\hline $5 e$ & 500 & $>1000$ & 1000 & NA & NA & NA \\
\hline $5 f$ & NA & $>1000$ & NA & NA & 250 & 250 \\
\hline $5 g$ & 500 & $>1000$ & NA & 500 & 125 & 125 \\
\hline $5 \mathrm{~h}$ & 1000 & $>1000$ & NA & NA & 250 & 250 \\
\hline $5 i$ & $>1000$ & NA & NA & $>1000$ & 31.5 & 62.5 \\
\hline $5 \mathbf{j}$ & 1000 & $>1000$ & $>1000$ & NA & 250 & 1000 \\
\hline $5 k$ & $>1000$ & $>1000$ & NA & NA & 125 & 250 \\
\hline 51 & 1000 & $>1000$ & NA & NA & NA & NA \\
\hline $5 \mathrm{~m}$ & 1000 & $>1000$ & $>1000$ & NA & 1000 & 500 \\
\hline $5 n$ & NA & $>1000$ & NA & NA & NA & NA \\
\hline 50 & 1000 & $>1000$ & NA & NA & 500 & 500 \\
\hline $5 p$ & 500 & $>1000$ & NA & NA & 250 & 250 \\
\hline $5 q$ & 1000 & $>1000$ & NA & NA & 125 & 250 \\
\hline Tet. & $24 \pm 0$ & $12 \pm 0.1$ & $9 \pm 0$ & $11 \pm 1.1$ & NT & NT \\
\hline Amp. B & NT & NT & $\mathrm{NT}$ & NT & $15 \pm 0.58$ & $14 \pm 0.1$ \\
\hline
\end{tabular}

Tet.: Tetracycline; Amp. B: Amphotericin B; MBC: Minimum Bactericidal activity; MFC: minimum fungicidal activity; NA: no activity. 


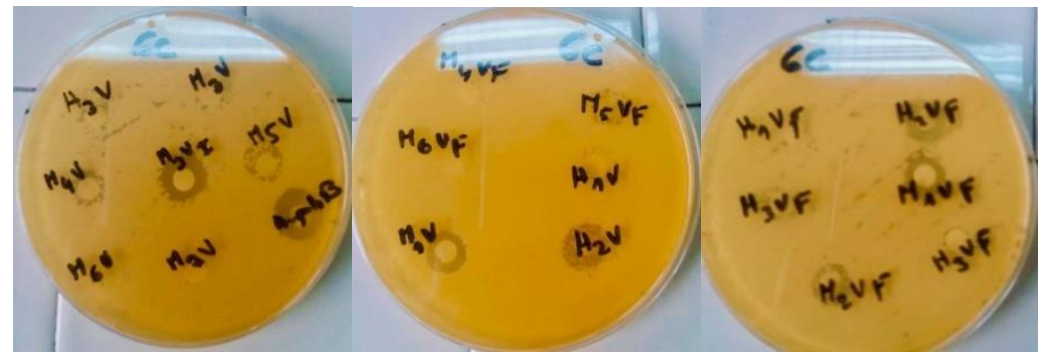

Yeast strains: test 6c-Candida krusei ATCC 6258

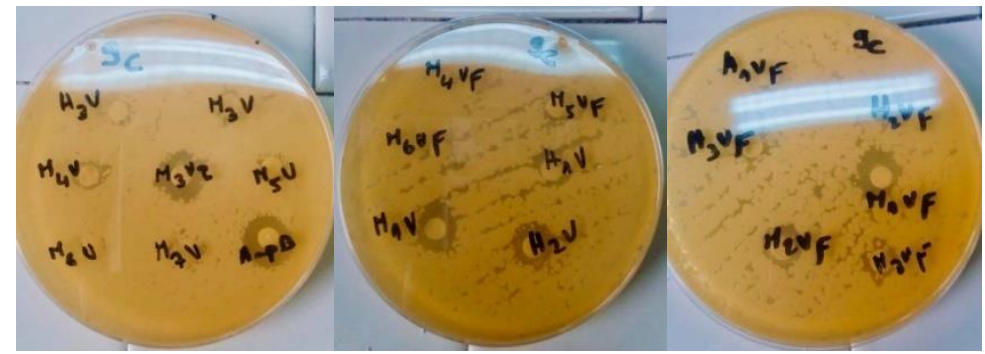

test 9c-Candida albicans ATCC 90028

Figure 6. Antibacterial activity of some derivatives via determination of the inhibition zone ( $\mathrm{mm})$ around discs impregnated with $\mathbf{5 a}(\mathrm{M} 1 \mathrm{~V}), \mathbf{5 b}(\mathrm{M} 2 \mathrm{~V}), \mathbf{5 c}(\mathrm{M} 3 \mathrm{~V}), \mathbf{5 d}(\mathrm{M} 4 \mathrm{~V}), \mathbf{5 e}(\mathrm{M} 7 \mathrm{~V}), \mathbf{5 f}(\mathrm{H} 1 \mathrm{~V}), \mathbf{5 g}(\mathrm{H} 2 \mathrm{~V})$, 5h (H3V), 5i (M1VF), 5j (M2VF), 5k (M3VF), 5 l (M4VF), 5m (M7VF), 5n (H1VF), 50 (H2VF), 5p (H3VF), and $5 q$ (M3VI) concentration (10 mg/disk).Tetracycline $(10 \mathrm{mg} / \mathrm{mL})$ or Amphotericin $\mathrm{B}(10 \mathrm{mg} / \mathrm{mL})$ expressed as mean $\pm \mathrm{SD}(\mathrm{n}=3)$.
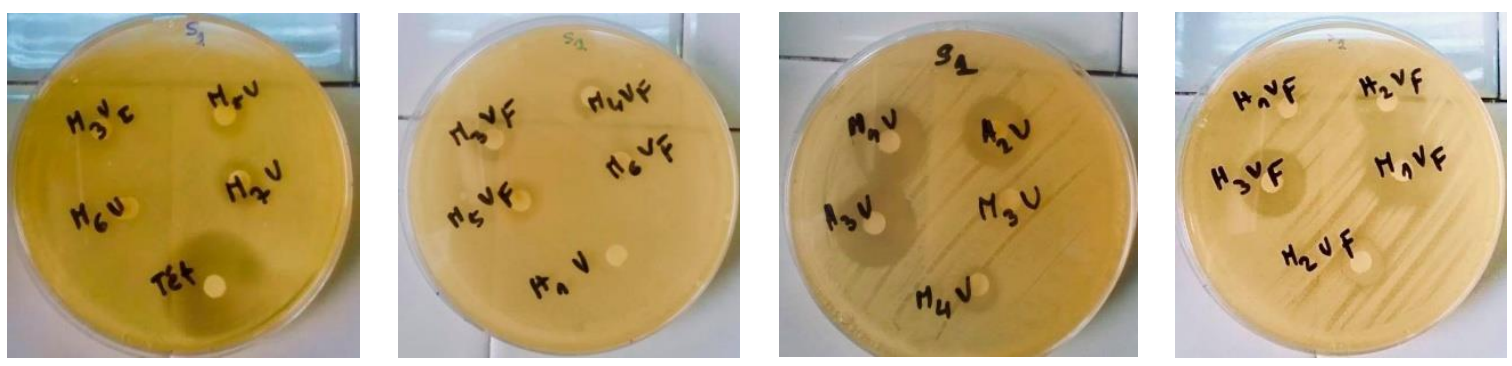

Gram-positive bacteria: test s1-Staphylococcus aureus ATCC 25923

Figure 7. Antimicrobial activity of some samples determined via the inhibition zone $(\mathrm{mm})$ around discs impregnated with 5a (M1V),5b (M2V), 5c(M3V), 5d(M4V), 5e(M7V),5f(H1V), 5g(H2V), 5h (H3V), 5i (M1VF), 5j (M2VF), 5k(M3VF), 5l(M4VF), 5m(M7VF), 5n(H1VF), 5o(H2VF), 5p(H3VF), and $5 \mathbf{q}(\mathrm{M} 3 \mathrm{VI})$ compounds (10 mg/disk); Tetracycline $(10 \mathrm{mg} / \mathrm{mL})$ or Amphotericin B $(10 \mathrm{mg} / \mathrm{mL})$ expressed as mean $\pm \mathrm{SD}(\mathrm{n}=3)$.

The highest antibacterial activity of the cycloadducts is display against gram-positive bacteria (Staphylococcus aureus ATCC 25,923 and Micrococcus luteus NCIMB 8166), whereas towards gram-negative bacteria (Escherichia coli ATCC 25,922 and Pseudomonas aeroginosa ATCC 27853), the probed compounds are in general less active compared to gram-positive ones.

In the first screening phase against Staphylococcus aureus ATCC 25923, 5a was noted to be the most sensitive derivative, with an inhibition zone of $31 \mathrm{~mm}$, the MIC being $3.9 \mu \mathrm{g} / \mathrm{mL}$ and the MBC being $31.5 \mu \mathrm{g} / \mathrm{mL}$, respectively (Tables 4-6). Then, against the same pathogenic bacteria, four compounds $\mathbf{5 d}, \mathbf{5 e}, \mathbf{5 h}$ and $\mathbf{5 l}$ showed an excellent activity with MIC values in the range of 31.5-62.5 $\mu \mathrm{g} / \mathrm{mL}$ as MBC with an inhibition zone between 11 and $20 \mathrm{~mm}$, compared to standard antibiotic Tetracycline.

When testing against Micrococcus luteus NCIMB 8166, compounds 5f, 5g, 5n and 50 were equipotent as Tetracycline. Thus, $5 \mathrm{~h}$ and $5 \mathrm{p}$ were found to be the most active, with 
MIC values of 31.5 and $62.5 \mu \mathrm{g} / \mathrm{mL}$, respectively (Table 4 ). Concerning the evaluation of the inhibition zone, the compounds $\mathbf{5 d}, \mathbf{5 o}$ and $\mathbf{5 p}$ were found to be the most sensitive, with $17 \mathrm{~mm}$ to $14 \mathrm{~mm}$. Additionally, the different compounds were evaluated against two gram-negative bacteria (Escherichia coli ATCC 25,922 and Pseudomonas aeroginosa ATCC 27853). In this case, $\mathbf{5 e}$ was found to be the most sensitive, with an inhibition zone of $15 \mathrm{~mm}$. All compounds were found to be equal or less active $(125->1000 \mu \mathrm{g} / \mathrm{mL})$ concerning the MIC or MBC compared to standard antibiotic Tetracycline.

On the other hand, the in vitro antifungal activity data reveal that $\mathbf{5 a}, \mathbf{5 f}$ and $\mathbf{5 i}$ display the highest activity with MIC $7.812 \mu \mathrm{g} / \mathrm{mL}$ against Amphotericin B.

Compounds 5d, 5k and $\mathbf{5 q}$ showed a somewhat less efficient activity, when compared to compounds $5 \mathbf{i}$ and $5 \mathbf{p}$ with MIC $31.5 \mu \mathrm{g} / \mathrm{mL}$ relating to Candida albicans ATCC 90028 . Additionally, regarding the results of antifungal screening, the MFC is noted to have good antifungal activity on $\mathbf{5 a}, 5 \mathbf{i}$ and $5 \mathbf{c}$ with $7.81,31.5$ and $62.5 \mu \mathrm{g} / \mathrm{mL}$, respectively. Furthermore, $\mathbf{5 b}$ appeared to be the most sensitive heterocycle $(14 \mathrm{~mm})$. In contrast, as indicated in Table 5, $\mathbf{n}$ n was revealed to be the least sensitive heterocycle, with an inhibition zone of $6 \mathrm{~mm}$.

Finally, we discuss the last yeast strains is Candida krusei ATCC 6258. In fact, $\mathbf{5 g}, \mathbf{5 i}$ and $5 p$ showed a superior sensitivity with an inhibition zone of $14-12 \mathrm{~mm}$. It is also worth mentioning the excellent antifungal activity of compounds 5a, displaying both a MIC and MFC of $31.5 \mu \mathrm{g} / \mathrm{mL}$ (Table 6).

\subsection{Molecular Docking Studies}

In order to provide a comprehensive rationale for the obtained biological activities, we docked the most active compounds,5a and $\mathbf{5 i}$, into glucosamine 6-phosphate synthase (GlcN6P) and methionyl-trna-synthetase (1PFV). GlcN6P catalyzes a multifarious reaction comprising both sugar isomerization (fructosamine-6-phosphate to glucosamine-6phosphate) and ammonia transfer (L-glutamine to Fru-6-P) [48-50]. This reaction initiates a pathway that finally drives the production of uridine 5 -diphospho- $N$-acetyl- $d$-glucosamine. This nucleotide sugar is used to assemble the macromolecules essential for constructing cell walls, such as the macromolecules with several amino sugar units, like chitin or proteins in fungi, and lipopolysaccharides and peptide glycan in bacteria. GlcN6P synthase inhibition is fatal, even for a short time, in prokaryotic cells but not in human cells. Therefore, it is considered as a promising target for developing antibacterial and antifungal agents.

The compounds, except 5a enantiomer (which has the most potent antibacterial activity among all the synthesized compounds), exhibit interactions with several amino acid residues at the active site of GlcN6P and reveal low binding energy. They also share several amino acids with the positive controls, Ampicillin and Tetracycline (Table 7) and (Figure 8).

Infections caused by antibiotic-resistant pathogens have raised markedly in recent years. Over $60 \%$ of staphylococcal infections in intensive care units in the United States, for example, are caused by methicillin-resistant bacterial strains. The incidence of the emerging methicillin-resistant staphylococcus aureus strains in community has raised many concerns.

These strains were found to express a wide range of virulence factors (https://en. wikipedia.org/wiki/Virulence_factor, accessed on 15 January 2021) and have an enhanced tendency toward progression into invasive ailments. The action takes place over two-step reactions. In the first step, methionine and ATP bind together to the enzyme's active site, resulting in the formation of methionyl adenylate, releasing pyrophosphate (PPi). In the following reaction, the activated methionyl adenylate is moved to tRNAMetat and its $3^{\prime}$ end, releasing an AMP molecule. MetRS has the unique ability to identify and load two tRNA substrates; namely, tRNAmMet and tRNAfMet [51]. For these reasons, the design of alternative antibacterial agents exhibiting an activity against drug-resistant staphylococci represents an important area for the development of novel drugs. 

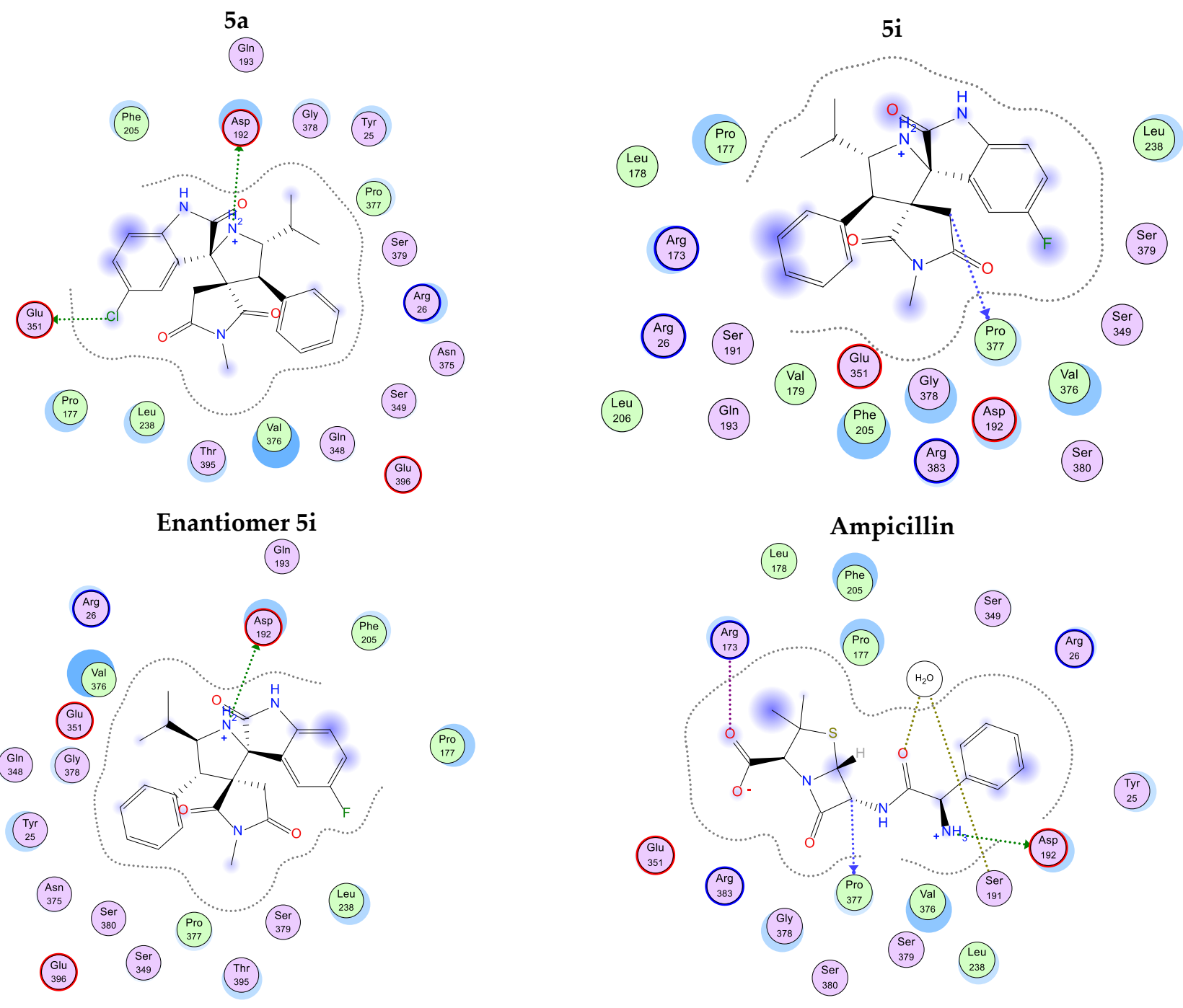

Tetracycline

GIn

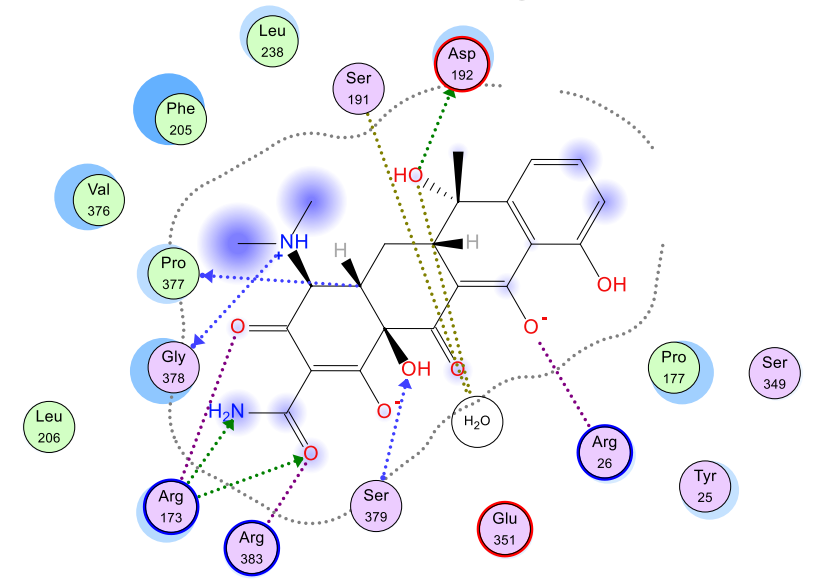

Figure 8. 2D-interactions of compounds 5a, 5i, $5 \mathbf{i}$ enantiomer, Ampicillin and Tetracycline with amino acid residues on glucosamine 6-phosphate synthase (1jxa). 
Table 7. Scoring function of docking poses and the interactions of the docked compounds $5 \mathbf{a}, 5 \mathbf{i}$, $5 \mathbf{i}$ enantiomer, Ampicillin and Tetracycline with amino acid residues on glucosamine 6-phosphate synthase (1jxa) and methionyl-trnas-ynthetase (1PFV).

\begin{tabular}{|c|c|c|c|c|}
\hline \multirow{2}{*}{ Comp. } & \multicolumn{2}{|c|}{ 1JXA } & \multicolumn{2}{|l|}{ 1PFV } \\
\hline & Ligand Interactions & Score Function & Ligand Interactions & Score Function \\
\hline $5 a$ & $\begin{array}{l}\text { ASP } 192 \text { (H-bonding) } \\
\text { GLU } 351 \text { (H-bonding) }\end{array}$ & -15.33 & $\begin{array}{l}\text { TYR } 15 \text { (Hydrophobic bonding and } \\
\text { H-bonding through solvent) } \\
\text { HIS } 24 \text { (H-bonding through solvent) }\end{array}$ & -12.09 \\
\hline 5a enantiomer & & Failed & & Failed \\
\hline $5 i$ & PRO 377 (H-bonding) & -13.40 & $\begin{array}{l}\text { HIS } 24 \text { (Hydrophobic bonding) } \\
\text { HIS } 21 \text { (Hydrophobic bonding) }\end{array}$ & -7.45 \\
\hline 5i enantiomer & ASP 192 (H-bonding) & -15.11 & $\begin{array}{l}\text { TYR } 15 \text { (H-bonding through solvent) } \\
\text { HIS } 24 \text { (H-bonding through solvent) }\end{array}$ & -12.51 \\
\hline Ampicillin & $\begin{array}{l}\text { ASP } 192 \text { (H-bonding) } \\
\text { SER } 191 \text { (H-bonding } \\
\text { through solvent) } \\
\text { ARG } 173 \text { (H-bonding) }\end{array}$ & -14.83 & $\begin{array}{l}\text { TYR } 15 \text { (H-bonding through solvent) } \\
\text { HIS } 24 \text { (H-bonding through solvent) } \\
\text { HIS } 21 \text { (H-bonding) } \\
\text { LYS } 335 \text { (H-bonding and salt bridge) }\end{array}$ & -9.99 \\
\hline Tetracycline & $\begin{array}{l}\text { PRO } 377 \text { (H-bonding) } \\
\text { ASP } 192 \text { (H-bonding) } \\
\text { SER } 191 \text { (H-bonding } \\
\text { through solvent) } \\
\text { ARG } 173 \text { (H-bonding } \\
\text { and salt bridge) } \\
\text { SER } 379 \text { (H-bonding) } \\
\text { GLY } 378 \text { (H-bonding) } \\
\text { ARG } 383 \text { (Salt bridge) } \\
\text { ARG } 26 \text { (Salt bridge) }\end{array}$ & -19.71 & $\begin{array}{l}\text { LYS } 335 \text { (Salt bridge) } \\
\text { HIS } 21 \text { (H-bonding) }\end{array}$ & -15.11 \\
\hline
\end{tabular}

Again, our in silico study results revealed that the screened compounds, except the 5a enantiomer, exhibited low binding energy when docked into methionyl-trna-synthetase $(1 \mathrm{PFV})$ and shared similar interactions with several amino acids similar to the positive control, Ampicillin and Tetracycline (Table 7) and Figure 9.

Interestingly, all compounds obeyed to the parameters of the rule of 5 (Lipinski rule) [52]. These include molecular weight, number of hydrogen bonds, accepting (lip_acc) and donating (lip_don) groups, and the drug-likeness potential (Table 8).

Table 8. Results of the Lipinski parameters of compounds 5a, 5i, $5 \mathbf{i}$ enantiomer, Ampicillin and Tetracycline.

\begin{tabular}{lccccc}
\hline \multirow{2}{*}{ Compound } & lip_acc & lip_don & lip_druglike & Weight & \multirow{2}{*}{ lip_violation } \\
\cline { 2 - 5 } & $\leq \mathbf{1 0}$ & $\leq \mathbf{5}$ & $\mathbf{- 1}$ & $\leq \mathbf{5 0 0}$ & \\
\hline $\mathbf{5 a}$ & 6 & 3 & 1 & 438.94 & 0 \\
$\mathbf{5 a}$ & 6 & 3 & 1 & 438.94 & 0 \\
enantiomer & 6 & 3 & 1 & 422.48 & 0 \\
$\mathbf{5 i}$ & 6 & 3 & 1 & 422.48 & 0 \\
$\mathbf{5 i}$ & 7 & 4 & 1 & 349.41 & 0 \\
enantiomer & 10 & 6 & 1 & 443.43 & 1 \\
Ampicillin & Tetracycline & & &
\end{tabular}



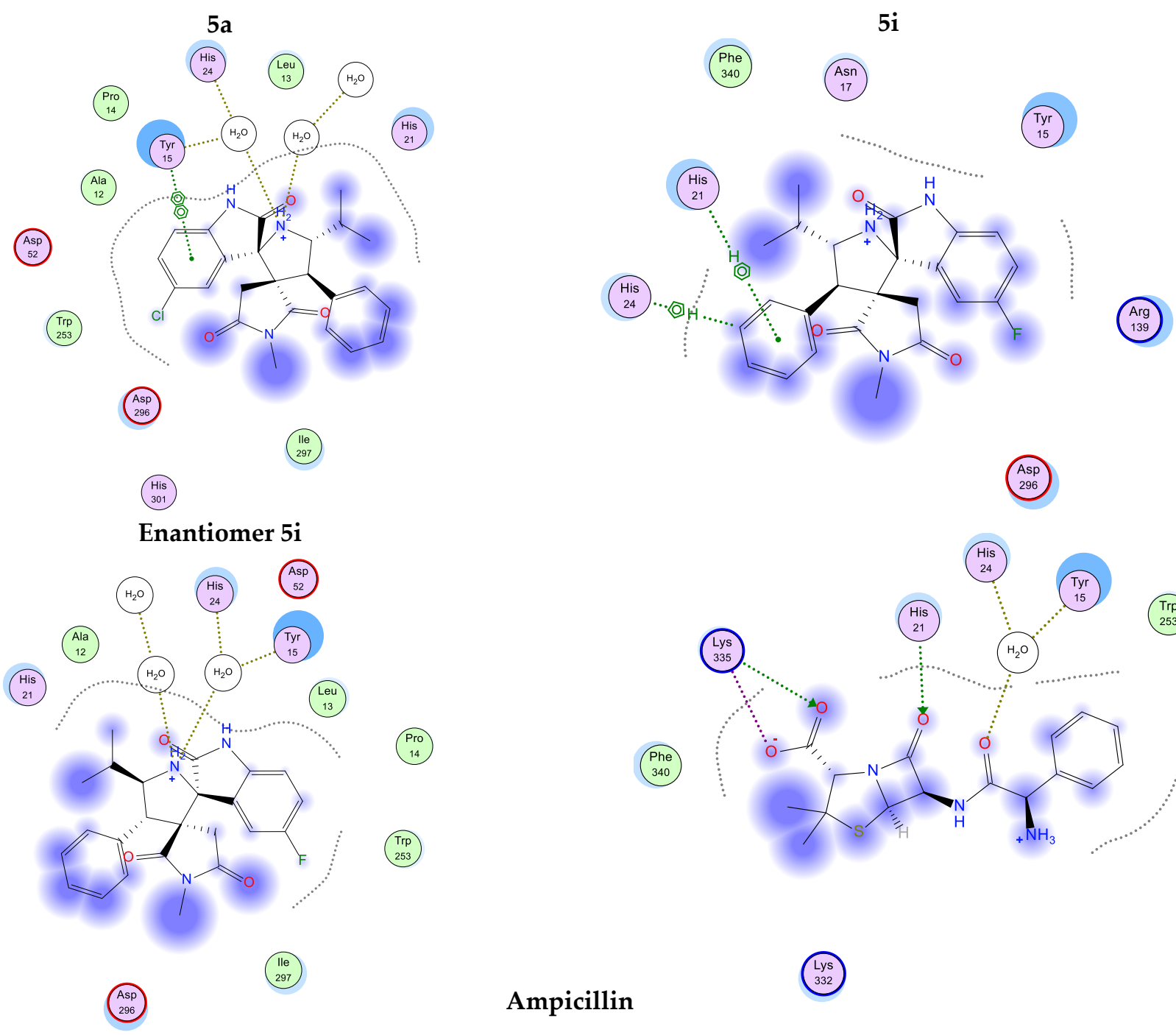

Ampicillin

$\left(\begin{array}{l}\text { Lys } \\ 332\end{array}\right.$

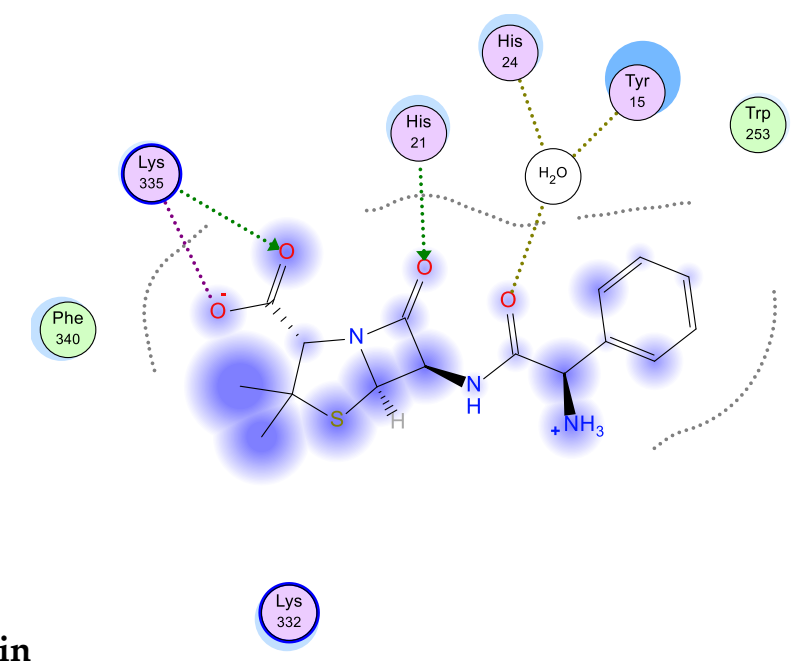

Leu

Tetracycline

Asp

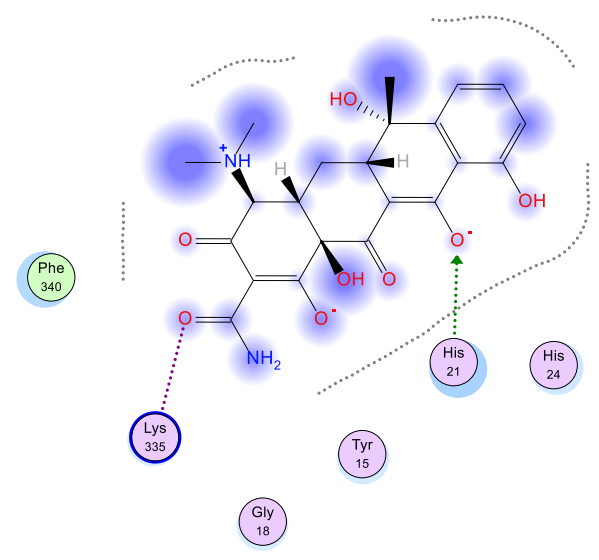

Figure 9. 2D-interactions of compounds $5 \mathbf{a}, 5 \mathbf{i}, \mathbf{5} \mathbf{i}$ enantiomer, Ampicillin and Tetracycline with amino acid residues on methionyl-trnasynthetase (1PFV). 


\section{Experimental}

\subsection{General Experimental Methods}

The ${ }^{1} \mathrm{H}$ NMR spectra were recorded at $400 \mathrm{MHz}$ using a Bruker Avance III-400 machine (Rheinstetten, Germany). The chemical shifts were recorded in ppm relative to TMS and with the solvent resonance as the internal standard. Data were reported as follows: chemical shift, multiplicity (bs = broad singlet, $\mathrm{s}=$ singlet, $\mathrm{d}=$ doublet, $\mathrm{dd}=$ doublet of doublet, $\mathrm{m}$ = multiplet), coupling constants (Hz), and integration. ${ }^{13} \mathrm{C}\left\{{ }^{1} \mathrm{H}\right\}$ NMR data were collected at $100 \mathrm{MHz}$ with complete proton decoupling with the solvent resonance as the internal standard. Optical absorption spectra were recorded at an ambient temperature, using a Shimadzu UV-3600 double-beam UV-visible spectrophotometer and the concentrations of spiro[pyrrolidin-2,3'-oxindole] derivatives were controlled to be of $10^{-5} \mathrm{M}$ in DMSO. The materials used were: thin-layer chromatography (TLC): TLC plates (Merck, silica gel 60 F254 $0.2 \mathrm{~mm} 200 \times 200 \mathrm{~nm}$ ), and substances were detected using UV light at $254 \mathrm{~nm}$. High Resolution Mass Spectra (ES-HRMS) were obtained with Micromass LCT (ESI technique, positive mode) spectrometers.

\subsection{X-ray Crystallography}

X-ray suitable crystal of $\mathbf{5 b}$ for the diffraction study were obtained by slow evaporation of a diethyl ether solution containing $5 \mathbf{b}$. The crystallographic data were collected at 193(2)K on a Bruker-AXS D8-Venture diffractometer equipped with a Photon III-C14 detector using MoK $_{\alpha}$ radiation $(\lambda=0.71073 \AA$ ). Phi- and omega-scans were used. Space group was determined on the basis of systematic absences and intensity statistics. Semi-empirical absorption correction was employed [53]. The structure was solved using an intrinsic phasing method (SHELXT) [54] and refined using the least-squares method on F [55]. All non-H atoms were refined with anisotropic displacement parameters. Hydrogen atoms were refined isotropically at calculated positions using a riding model with their isotropic displacement parameters constrained to be equal to 1.5 times the equivalent isotropic displacement parameters of their pivot atoms for terminal $\mathrm{sp}^{3}$ carbon and 1.2 times for all other carbon atoms. $\mathrm{H}$ on nitrogen atoms were located by difference Fourier maps.

CCDC-2063918 contains the supplementary crystallographic data for this paper. These data can be obtained free of charge from The Cambridge Crystallographic Data Centre via https: / / www.ccdc.cam.ac.uk/structures (accessed on 19 Mars 2021).

Crystal data for $5 \mathbf{b}: \mathrm{C}_{25} \mathrm{H}_{26} \mathrm{ClN}_{3} \mathrm{O}_{3}(M=451.94 \mathrm{~g} / \mathrm{mol})$ : Monoclinic, space group $P 21 / c, a$ $=12.8755(8) \AA, b=25.4246(16) \AA, c=14.9546(9) \AA, \beta=100.370(2)^{\circ}, V=4815.5(5) \AA^{3}, Z=8$, crystal size $0.40 \times 0.08 \times 0.06 \mathrm{~mm}^{3}, \mu(\mathrm{MoK} \alpha)=0.189 \mathrm{~mm}^{-1}$, Dcalc $=1.247 \mathrm{~g} / \mathrm{cm}^{3}, 163,328$ reflections collected, 13,498 unique $\left(R_{\text {int }}=0.1293\right), 601$ parameters, $R 1[\mathrm{I}>2 \mathrm{~s}(\mathrm{I})]=0.0584$, $w R 2$ [all data] $=0.1428$, and the largest differential peak and hole: 0.516 and $-0.343 \mathrm{e}^{-3}$.

\subsection{Antimicrobial Screening}

First, the optical density of each microorganism suspensions was adjusted to 0.1 at OD600 for bacteria and 0.4 at OD540 for yeasts. Then, $500 \mu \mathrm{L}$ of inoculums were dropped onto adequate agar plates. Sterile filter discs (diameter $6 \mathrm{~mm}$, Biolife, Italy) were placed at the surface of the appropriate agar mediums and $10 \mathrm{mg} /$ disc of the product dissolved in $10 \%$ of dimethyl sulfoxide was dropped onto each disc. Tetracycline $(10 \mathrm{mg} / \mathrm{mL} ; 10 \mu \mathrm{L} / \mathrm{disc})$ and Amphotericin B (10 mg/mL; $10 \mu \mathrm{L} /$ disc), were used as reference drugs. After incubation for $18-24 \mathrm{~h}$ at $37{ }^{\circ} \mathrm{C}$, the antibacterial activities were evaluated by measuring an inhibition zone formed around the disc. Each assay was performed in triplicate.

For this, the microbial inoculums were prepared from $12 \mathrm{~h}$ broth cultures and spectrophotometrically adjusted to $10^{7} \mathrm{UFC} / \mathrm{mL}$.

Serial two-fold dilutions of the different amounts of the compounds (1000 to $0.09 \mu \mathrm{g} / \mathrm{mL}$ ) were prepared in adequate broth. Then, $10 \mu \mathrm{L}$ of the inocula of each reference strain were added to the plates containing the serial dilution and were incubated aerobically at $37{ }^{\circ} \mathrm{C}$ for $24 \mathrm{~h}$. MIC was defined as the lowest concentration that completely inhibited visible cell growth during $24 \mathrm{~h}$ incubation period at $37^{\circ} \mathrm{C}$. 
MBC and MFC values were determined by inoculating $10 \mu \mathrm{L}$ of each well medium with no visible growth on Müller Hinton or Sabouraud chromphenicol agar plates (https: / / en.wikipedia.org/wiki/Sabouraud_agar, accessed on 17 January 2021) and were defined as the lowest concentration at which $99 \%$ of the tested strains were killed after $24 \mathrm{~h}$ of incubation at $37^{\circ} \mathrm{C}$.

\subsection{General Procedure for the Preparation of Cycloadducts 5}

The (E)-3-arylidene-1-metylpyrrolidine-2,5-diones $4 \mathbf{a}-\mathbf{h}$ have been synthesized by Wittig reaction between $N$-methylmaleimide and the corresponding aromatic aldehyde [56].

A mixture of isatin derivatives $1(1 \mathrm{mmol}), L$-valine $2(1.2 \mathrm{mmol})$ and dipolaphile 4 $(1 \mathrm{mmol})$ was refluxed in methanol $(10 \mathrm{~mL})$ for $3 \mathrm{~h}$. After completion of the reaction as monitored from TLC, the solvent was removed under reduced pressure and the residue was chromatographed on silica gel employing ethylacetate-heptane (3:7 v/v) as eluent to obtain the pure products 5. Spectroscopic data for all compounds are presented in the ESI.

\section{Conclusions}

To resume, we reported the synthesis of a series spiro[oxindole-2, 3 '-pyrrolidine] tethered with succinimide scaffolds via a three component 1,3-dipolar cycloaddition reaction of (E)-3-arylidene-1-methyl-pyrrolidine-2,5-diones, $L$-valine and cyclic ketones of the isatin type. The antimicrobial activity of these heterocyclic compounds was investigated against six microbial strains. The screening results showed that most of the tested compounds showed moderate to excellent antibacterial and antifungal activities. Molecular docking studies indicates that two compounds,5a and $5 \mathbf{i}$, had the most potent antibacterial and antifungal activities among all the synthesized compounds, revealing interactions with several amino acid residues at active site of GlcN6P and revealing low binding energy. The predicted ADME profiles of the compounds $\mathbf{5 a}$ and $5 \mathbf{i}$ are in line with the Lipinski rules.

Supplementary Materials: The following supporting information can be downloaded at: https: / / www.mdpi.com/article/10.3390/app12010360/s1, compound characterization data and Figures S1-S34: ${ }^{1} \mathrm{H}$ and ${ }^{13} \mathrm{C}-\mathrm{NMR}$ spectra, additional crystallographic data.

Author Contributions: Conceptualization, methodology, software, and formal analysis, S.A., A.D., C.M., S.B., E.R., O.L., N.S.-M. and R.G.; software, investigation, S.B., M.K. and R.G.; writing-original draft preparation, S.A. and S.B.; writing-review and editing, S.B.; M.K. and R.G.; visualization, supervision, and project administration, M.K. All authors have read and agreed to the published version of the manuscript.

Funding: This work was supported by the LR11ES39 and LR21ES04 Grant from the Ministry of Higher Education and Scientific Research, Tunisia.

Institutional Review Board Statement: Not applicable.

Informed Consent Statement: Not applicable.

Data Availability Statement: Not applicable.

Acknowledgments: We thank Mansour Sobeh for performing the docking analyses.

Conflicts of Interest: The authors declare no conflict of interest.

\section{References}

1. Dunn, P.J. The importance of Green Chemistry in Process Research and Development. Chem. Soc. Rev. 2012, 41, 1452-1461. [CrossRef]

2. Ruijter, E.; Scheffelar, R.; Orru, R.V.A. Multicomponent Reaction Design in the Quest for Molecular Complexity and Diversity. Angew. Chem. Int. Ed. 2011, 50, 6234-6246. [CrossRef]

3. Ganem, B. Strategies for Innovation in Multicomponent Reaction Design. Acc. Chem. Res. 2009, 42, 463-472. [CrossRef]

4. Zhu, J.; Bienayme, H. Multicomponent Reactions; Wiley Online Library: Hoboken, NJ, USA, 2005; pp. 468-469. [CrossRef]

5. Graaff, C.; Ruijter, E.; Orru, R.V.A. Recent developments in asymmetric multicomponent reactions. Chem. Soc. Rev. 2012, 41, 3969-4009. [CrossRef] 
6. Zheng, Y.; Tice, C.M.; Singh, S.B. The use of spirocyclic scaffolds in drug discovery. Bioorg. Med. Chem. Lett. 2014, $24,3673-3682$. [CrossRef] [PubMed]

7. Kotha, S.; Panguluri, N.R.; Ali, R. Design and Synthesis of Spirocycles. Eur. J. Org. Chem. 2017, 5316-5342. [CrossRef]

8. Sebahar, P.R.; Williams, R.M. The Asymmetric Total Synthesis of (+)- and (-)-Spirotryprostatin B. J. Am. Chem. Soc. 2000, 122, 5666-5667. [CrossRef]

9. Singh, G.S.; Desta, Z.Y. Isatins as Privileged Molecules in Design and Synthesis of Spiro-Fused Cyclic Frameworks. Chem. Rev. 2012, 112, 6104-6155. [CrossRef]

10. Girgis, A.S. Regioselective synthesis of dispiro $\left[1 H\right.$-indene-2, $3^{\prime}$-pyrrolidine-2',3"-[3H]indole]-1,2" $\left(1^{\prime \prime} H\right)$-diones of potential anti-tumor properties. Eur. J. Med. Chem. 2009, 44, 91-100. [CrossRef] [PubMed]

11. George, R.F.; Ismail, N.S.M.; Stawinski, J.; Girgis, A.S. Design, synthesis and QSAR studies of dispiroindole derivatives as new antiproliferative agents. Eur. J. Med. Chem. 2013, 68, 339-351. [CrossRef] [PubMed]

12. Hussein, E.M.; Abdel-Monem, M.I. Regioselective synthesis and anti-inflammatory activity of novel dispiro[pyrazolidine-4,3'pyrrolidine-2', 3"'-indoline]-2",3,5-triones. Arkivoc 2011, 10, 85-98. [CrossRef]

13. Kumar, R.S.; Rajesh, S.M.; Perumal, S.; Banerjee, D.; Yogeeswari, P.; Sriram, D. Novel three-component domino reactions of ketones, isatin and amino acids: Synthesis and discovery of antimycobacterial activity of highly functionalised novel dispiropyrrolidines. Eur. J. Med. Chem. 2010, 45, 411-422. [CrossRef]

14. Raj, A.A.; Raghunathan, R.; Kumari, M.R.S.; Raman, N. Synthesis, Antimicrobial and Antifungal Activity of a New Class of Spiro pyrrolidines. Bioorg. Med. Chem. 2003, 11, 407-419. [CrossRef]

15. Periyasami, G.; Raghunathan, R.; Surendiran, G.; Mathivanan, N. Synthesis of novel spiropyrrolizidines as potent antimicrobial agents for human and plant pathogens. Bioorg. Med. Chem. Lett. 2008, 18, 2342-2345. [CrossRef]

16. Thangamani, A. Regiospecific synthesis and biological evaluation of spirooxindolopyrrolizidines via [3+2] cycloaddition of azomethine ylide. Eur. J. Med. Chem. 2010, 45, 6120-6126. [CrossRef] [PubMed]

17. Arun, Y.; Bhaskar, G.; Balachandran, C.; Ignacimuthuand, S.; TPerumal, P. Facile one-pot synthesis of novel dispirooxindolepyrrolidine derivatives and their antimicrobial and anticancer activity against A549 human lung adenocarcinoma cancer cell line. Bioorg. Med. Chem. Lett. 2013, 23, 1839-1845. [CrossRef] [PubMed]

18. Ali, M.A.; Ismail, R.; Choon, T.S.; Yoon, Y.K.; Wei, A.C.; Pandian, S.; Kumar, R.S.; Osman, H.; Manogaran, E. Substituted spiro [2.3'] oxindolespiro [3.2"]-5,6-dimethoxy-indane-1"-one-pyrrolidine analogue as inhibitors of acetylcholinesterase. Bioorg. Med. Chem. Lett. 2010, 20, 7064-7066. [CrossRef] [PubMed]

19. Kia, Y.; Osman, H.; Kumar, R.S.; Murugaiyah, V.; Basiri, A.; Perumal, S.; Wahab, H.A.; Bing, C.S. Synthesis and discovery of novel piperidone-grafted mono- and bis-spirooxindole-hexahydropyrrolizines as potent cholinesterase inhibitors. Bioorg. Med. Chem. 2013, 7, 1696-1707. [CrossRef]

20. Chandraprakash, K.; Sankaran, M.; Uvarani, C.; Shankar, R.; Ata, A.; Dallemer, F.; Mohan, P.S. A strategic approach to the synthesis of novel class of dispiroheterocyclic derivatives through 1,3 dipolar cycloaddition of azomethine ylide with (E)-3arylidene-2,3-dihydro-8-nitro-4-quinolone. Tetrahedron Lett. 2013, 54, 3896-3901. [CrossRef]

21. Alimohammadi, K.; Sarrafi, Y.; Tajbakhsh, M.; Yeganegi, S.; Hamzehloueian, M. An experimental and theoretical investigation of the regio- and stereoselectivity of the polar [3+2] cycloaddition of azomethine ylides to nitrostyrenes. Tetrahedron 2011, 67, 1589-1597. [CrossRef]

22. Ghandi, M.; Taheri, A.; Abbasi, A. A facile synthesis of chromeno[3,4-c]spiropyrrolidine-oxindoles via 1,3-dipolar cycloadditions. Tetrahedron 2010, 66, 6744-6748. [CrossRef]

23. Moghaddam, F.M.; Khodabakhshi, M.R.; Ghahremannejad, Z.; Foroushani, B.K.; Ng, S.W. A one-pot, three-component regiospecific synthesis of dispiropyrrolidines containing a thiophenone ring via 1,3-dipolar cycloaddition reactions of azomethine ylides. Tetrahedron Lett. 2013, 54, 2520-2524. [CrossRef]

24. Dandia, A.; Singh, R.; Joshi, J.; Kumari, S. An eco-compatible synthesis of medicinally important novel class of trispiroheterocyclic framework using 2,2,2-trifluoroethanol as a reusable medium. J. Fluor. Chem. 2013, 156, 283-289. [CrossRef]

25. Xiao, J.; Zhang, H.; Liang, S.; Ren, J.; Yang, H.; Chen, H. Synthesis of Pyrrolo(spiro-[2.3']-oxindole)-spiro-[4.3"]-oxindole via 1,3-Dipolar Cycloaddition of Azomethine Ylides with 3-Acetonylideneoxindole. J. Org. Chem. 2013, 78, 11577-11583. [CrossRef]

26. Hu, Y.; Zou, Y.; Wu, H.; Shi, D. A facile and efficient ultrasound-assisted synthesis of novel dispiroheterocycles through 1,3-dipolar cycloaddition reactions. Ultrason. Sonochem. 2012, 19, 264-269. [CrossRef]

27. Rajesh, R.; Raghunathan, R. Regio- and stereoselective synthesis of novel tetraspiro-bispyrrolidine and bisoxindolopyrrolidine derivatives through 1,3-dipolar cycloaddition reaction. Tetrahedron Lett. 2010, 51, 5845-5848. [CrossRef]

28. Isaka, M.; Rugseree, N.; Maithip, P.; Kongsaeree, P.; Prabpai, S.; Thebtaranonth, Y. Hirsutellones A-E, antimycobacterial alkaloids from the insect pathogenic fungus Hirsutellanivea BCC 2594. Tetrahedron 2005, 61, 5577-5583. [CrossRef]

29. Matviiuk, T.; Mori, G.; Lherbet, C.; Rodriguez, F.; Pasca, M.R.; Gorichko, M.; Guidetti, B.; Voitenko, Z.; Baltas, M. Synthesis of 3-heteryl substituted pyrrolidine-2,5-diones via catalytic Michael reaction and evaluation of their inhibitory activity against InhA and Mycobacterium tuberculosis. Eur. J. Med. Chem. 2014, 71, 46-52. [CrossRef]

30. Zhao, S.; Li, H.; Chang, X.; Wang, J.; Zhao, E.; Yin, Z.; Mao, X.; Deng, S.; Haoand, T.; Wang, H. Synthesis, in vitro stability, and antiproliferative effect of d-cysteine modified GnRH-doxorubicin conjugates. J. Pept. Sci. 2019, 25, e3135. [CrossRef] 
31. Socala, K.; Mogilski, S.; Pieróg, M.; Nieoczym, D.; Abram, M.; Szulczyk, B.; Lubelska, A.; Latacz, G.; Doboszewska, U.; Wla, P.; et al. KA-11, A Novel Pyrrolidine-2,5-dione Derived Broad-Spectrum Anticonvulsant: Its Antiepileptogenic, Antinociceptive Properties and in vitro Characterization. ACS Chem. Neurosci. 2019, 10, 636-648. [CrossRef] [PubMed]

32. Rapacz, A.; Obniska, J.; Wiklik-Poudel, B.; Rybka, S.; Sałat, K.; Filipek, B. Analgesic, antiallodynic, and anticonvulsant activity of novel hybrid molecules derived from N-benzyl-2-(2,5-dioxopyrrolidin-1-yl)propanamide and 2-(2,5-dioxopyrrolidin-1yl)butanamide in animal models of pain and epilepsy. Eur. J. Pharmacol. 2016, 781, 239-249. [CrossRef]

33. Boudriga, S.; Haddad, S.; Murugaiyah, V.; Askri, M.; Knorr, M.; Strohmann, C.; Golz, C. Three-component Access to Functionalized Spiropyrrolidine Heterocyclic Scaffolds and Their Cholinesterase Inhibitory Activity. Molecules 2020, 25, 1963. [CrossRef]

34. Askri, S.; Edziri, H.; Ben Hamouda, M.; Mchiri, C.; Gharbi, R.; Abd El-Gawad, H.H.; El-Tahawy, M.M.T. Synthesis, Biological Evaluation, Density Functional Calculation and Molecular Docking Analysis of Novel Spiropyrrolizidines Derivatives as Potential Anti-Microbial and Anti-Coagulant Agents. J. Mol. Struct. 2022, 1250, 13688. [CrossRef]

35. Toumi, A.; Boudriga, S.; Hamden, K.; Daoud, I.; Askri, M.; Soldera, A.; Lohier, J.-F.; Strohmann, C.; Brieger, L.; Knorr, M. Diversityoriented Synthesis of Spiropyrrolo[1,2-a]isoquinoline Derivatives via Diastereoselective and Regiodivergent Three-component 1,3-Dipolar Cycloaddition Reactions: In vitro and in vivo Evaluation of the Antidiabetic Activity of New Rhodanine Analogues. J. Org. Chem. 2021, 86, 13420-13445. [CrossRef]

36. Toumi, A.; Boudriga, S.; Hamden, K.; Sobeh, M.; Cheurfa, M.; Askri, M.; Knorr, M.; Strohmann, C.; Brieger, L. Synthesis, antidiabetic activity and molecular docking study of rhodanine-substitued spirooxindole pyrrolidine derivatives as novel $\alpha$-amylase inhibitors. Bioorg. Chem. 2021, 106, 104507. [CrossRef]

37. Boudriga, S.; Elmhawech, B.; Askri, M. Straightforward and Highly Diastereoselective Synthesis of a New Set of Functionalized Dispiropyrrolidines Involving Multicomponent 1,3-Dipolar Cycloaddition with Azomethine Ylides. J. Heterocycl. Chem. 2019, 56, 1748-1756. [CrossRef]

38. Boudriga, S.; Haddad, S.; Askri, M.; Soldera, A.; Knorr, M.; Strohmann, C.; Golz, C. Highly Diastereoselective Donstruction of Noveldispiropyrrolo[2,1-a]isoquinoline Derivatives via Multicomponent 1,3-Dipolar Cycloaddition of Cyclic Diketones-Based TetrahydroisoquinoliniumN-Ylides. RSC Adv. 2019, 9, 11082-11091. [CrossRef]

39. Haddad, S.; Boudriga, S.; Akhaja, T.N.; Raval, J.P.; Porzio, F.; Soldera, A.; Askri, M.; Knorr, M.; Rousselin, Y.; Kubicki, M.M.; et al. A Strategic Approach to the Synthesis of Functionalized Spirooxindole Pyrrolidine Derivatives: In vitro Antibacterial, Antifungal, Antimalarial and Antitubercular studies. New J. Chem. 2015, 39, 520-528. [CrossRef]

40. Haddad, S.; Boudriga, S.; Parzo, F.; Soldera, A.; Askri, M.; Knorr, M.; Rousselin, Y.; Kubicki, M.M.; Golz, C.; Strohmann, C. Regioand Stereoselective Synthesis of Spiropyrrolizidines and Piperazines through Azomethine Ylide Cycloaddition Reaction. J. Org. Chem. 2015, 80, 9064-9075. [CrossRef]

41. Mhiri, C.; Boudriga, S.; Askri, M.; Knorr, M.; Sriram, D.; Yogeeswari, P.; Nana, F.; Golz, C.; Strohmanni, C. Design of Novel Dispirooxindolopyrrolidine and Dispirooxindolopyrrolothiazole Derivatives as Potential Antitubercular Agents. Bioorg. Med. Chem. Lett. 2015, 25, 4308-4313. [CrossRef]

42. Houk, K.N. The Role of Secondary Orbital Interactions in Cycloaddition Reactions. Tetrahedron Lett. 1970, 30, 2621-2624. [CrossRef]

43. Peng, C.; Ren, J.; Xiao, J.-A.; Zhang, H.; Yang, H.; Luo, Y. Additive-assisted regioselective 1,3-dipolar cycloaddition of azomethine ylides with benzylideneacetone. Beilstein J. Org. Chem. 2014, 10, 352-360. [CrossRef]

44. Dilling, W.L. The Effect of Solvent on the Electronic Transitions of Benzophenone and its o- and p-Hydroxy Derivatives. J. Org. Chem. 1996, 31, 1045-1050. [CrossRef]

45. Ivanova, B.; Kolev, T. Linearly Polarized IR Spectroscopy Theory and Applications for Structural Analysis; Stanford Libraries: Stanford, CA, USA, 2011.

46. Tauc, J.; Grigorovici, R.; Vancu, A. Optical Properties and Electronic Structure of Amorphous Germanium. Phys. Status Solidi B 1966, 15, 627-637. [CrossRef]

47. Snoussi, M.; Noumi, E.; Trabelsi, N.; Flamini, G.; Papetti, A.; de Feo, V. Mentha spicata Essential Oil: Chemical Composition, Antioxidant and Antibacterial Activities against Planktonic and Biofilm Cultures of Vibrio spp. Strains. Molecules 2015, 20, 14402-14424. [CrossRef] [PubMed]

48. Milewski, S. Glucosamine-6-phosphate synthase-The multi-facets enzyme. Biochim. Biophys. Acta 2002, 1597, 173-192. [CrossRef]

49. Durand, P.; Golinelli-Pimpaneau, B.; Mouilleron, S.; Badet, B.; Badet-Denisot, M.A. Highlights of glucosamine-6P synthase catalysis. Arch. Biochem. Biophys. 2008, 474, 302-317. [CrossRef]

50. Hollenhorst, M.A.; Ntai, I.; Badet, B.; Kelleher, N.L.; Walsh, C.T. A Head-to-Head Comparison of Eneamide and Epoxyamide Inhibitors of Glucosamine-6-Phosphate Synthase from the Dapdiamide Biosynthetic Pathway. Biochemistry 2011, 50, 3859-3861. [CrossRef]

51. National Nosocomial Infections Surveillance System. National Nosocomial Infections Surveillance (NNIS) System Report, data summary from January 1992 through June 2004, issued October 2004. Am. J. Infect. Control 2004, 32, 470. [CrossRef]

52. Lipinski, C.A. Lead- and drug-like compounds: The rule-of-five revolution. Drug Discov. Today Technol. 2004, 1, 337-341. [CrossRef]

53. Dolomanov, O.V.; JBourhis, L.; Gildea, R.J.; Howard, J.A.K.; Puschmann, H. OLEX2: A complete structure solution, refinement and analysis program. J. Appl. Crystallogr. 2009, 42, 339-341. [CrossRef] 
54. Sheldrick, G.M. SHELXT-Integrated space-group and crystal-structure determination. Acta Crystallogr. A 2015, 71, 3-8. [CrossRef] [PubMed]

55. Sheldrick, G.M. Crystal structure refinement with SHELXL. Acta Crystallogr. C 2015, 71, 3-8. [CrossRef] [PubMed]

56. Yan, L.; Yang, W.; Li, L.; Shen, Y.; Jiang, Z. A One-pot Green Synthesis of Alkylidenesuccinimides. Chin. J. Chem. 2011, 29, 1906-1910. [CrossRef] 